\title{
KESAHAN DAN KEBOLEHPERCAYAAN INSTRUMEN PENILAIAN KENDIRI PEMBELAJARAN GEOMETRI TINGKATAN SATU
}

\section{(LEARNING FORM ONE GEOMETRY: VALIDITY AND RELIABILITY OF A SELF-EVALUATION INSTRUMENT)}

\author{
${ }^{1}$ Mohd Faizal Nizam Lee Abdullah \& Leow Tze Wei \\ Faculty of Science and Mathematics \\ Universiti Pendidikan Sultan Idris, Malaysia
}

${ }^{1}$ Corresponding author: faizalee@fsmt.upsi.edu.my

\begin{abstract}
ABSTRAK
Tujuan - Membina satu instrumen untuk membolehkan murid membuat penilaian kendiri ke atas pembelajaran geometri Tingkatan Satu dan menentukan kesahan kandungan dan kebolehpercayaan instrumen berkenaan.

Metodologi - Pembinaan instrumen adalah berpandukan Model Penilaian Konteks-Input-Proses-Produk (KIPP). Kajian ini melibatkan tiga fasa iaitu, kajian literatur, pembinaan instrumen kajian dan analisis kesahan kandungan dan kebolehpercayaan instrumen. Instrumen yang dibina adalah berbentuk rubrik dua lapis. Jadual Spesifikasi Instrumen digunakan dalam proses pembinaan item-item penilaian. Kemudian kesahan item disemak oleh panel pakar berkenaan. Data kuantitatif yang dikumpul dari kajian rintis dan kajian sebanar dianalisis dengan menentukan nilai pekali Cronbach Alpha. Pembinaan item merujuk kepada takrifan konstruk berasaskan kajian literatur. Kajian literatur menunjukkan terdapat lima konstruk iaitu, pengetahuan sedia ada murid, kefahaman murid dalam geometri, gaya pembelajaran murid, sikap pembelajaran murid serta pendekatan pengajaran guru. Sebanyak 79 item telah dibangunkan dalam instrumen ini. Kesemua lima panel pakar
\end{abstract}


dalam bidang Pendidikan Matematik bersetuju bahawa instrumen yang dibina mempunyai kesahan kandungan yang boleh diterima. Untuk menentukan pekali kebolehpercayaan instrumen, kajian ini telah dilaksanakan di tiga buah sekolah menengah dalam daerah Kuala Kangsar, Perak. Seramai 400 orang murid Tingkatan Dua dipilih sebagai sampel kajian. Perisian Statistical Package for Social Science (SPSS versi 20) digunakan untuk menganalisis data yang diperoleh daripada hasil kajian.

Dapatan - Kajian rintis dan kajian sebenar telah dijalankan dalam kajian ini. Tujuannya adalah untuk melihat kestabilan nilai Cronbach Alpha yang diperoleh melalui kajian rintis dan kajian sebenar. Bagi menentukan sama ada item yang dibina diterima atau disingkirkan, penyelidik membuat perbandingan nilai Cronbach Alpha jika item disingkirkan (Alpha If Item Deleted) bagi setiap item dengan nilai Cronbach Alpha bagi konstruk yang terlibat dalam instrumen tersebut. Selain itu, nilai Cronbach Alpha yang diperoleh daripada kedua-dua kajian diinterpretasi berdasarkan Jadual Nilai Kebolehpercayaan. Kebolehpercayaan Cronbach Alpha bagi kelima-lima konstruk dalam kajian rintis berada antara 0.722 dan 0.945. Manakala, kebolehpercayaan Cronbach Alpha bagi kelimalima konstruk dalam kajian sebenar berada antara 0.813 dan 0.940 . Tambahan pula, nilai keseluruhan Cronbach Alpha instrumen penilaian bagi kajian rintis dan kajian sebenar masing-masing menunjukkan 0.955 dan 0.946 yang berada pada tahap amat baik.

Signifikan - Penghasilan instrumen penilaian kendiri pembelajaran geometri yang berpandukan Model KIPP dapat membantu murid mengetahui tahap penguasaannya terhadap topik-topik geometri yang dipelajari dan berusaha untuk membaiki kelemahan dalam pembelajaran mereka. Instrumen penilaian ini juga boleh dijadikan sebagai sumber rujukan guru dalam membantu perancangan strategi pembelajaran dan pengajaran topik geometri yang lebih berkesan. Instrumen penilaian kendiri ini boleh dijadikan sebagai panduan bagi melihat sejauh manakah hasil pembelajaran topik Geometri Tingkatan Satu telah tercapai dengan optimum bersesuaian dengan sasaran dan tujuan pembelajaran itu sendiri.

Kata kunci: Instrumen penilaian kendiri, pembelajaran geometri, kesahan dan kebolehpercayaan, pendidikan matematik. 


\section{ABSTRACT}

Purpose- This study sought to develop an instrument to evaluate student learning of Form One geometry and to determine the content validity and reliability of the self-learning evaluation instrument.

Methodology - The development of the instrument is based on the Context-Input-Process-Product Evaluation Model (CIPP). The study involved three phases comprising the literature review, the development of the research instrument, and the analysis of the instrument's content validity and reliability. The instrument which was developed took the form of a two-layered rubric. The item construction and construct definition were based on the literature review. The review of the literature showed that there were five constructs, namely the existing knowledge of students, their understanding of geometry, their learning style, their attitude in learning and the teaching approach of their teachers. A total of 79 items was developed in this instrument. All five members of the panel of experts in the field of Mathematics Education agreed that the instrument developed had acceptable content validity. To determine the instrument's coefficient reliability, a study was conducted in three secondary schools in the district of Kuala Kangsar, Perak. A total of 400 Form Two students were selected as the population sample. The Statistical Package for Social Science (SPSS version 20) software was used to analyze the data obtained from the study.

Findings - Apart from the main study, a pilot study was also conducted. The aim was to determine the stability of the Cronbach Alpha obtained through the pilot study as well as in the main study. In determining whether an item construct could be accepted or eliminated, the researchers compared the Cronbach Alpha values. An item was deleted if its Cronbach Alpha was not within the acceptable range. In addition, the Cronbach Alpha obtained from both studies was interpreted based on a Value Reliability Table. The reliability of Cronbach Alpha for the five constructs in the pilot study was between 0.722 and 0.945 . However, the reliability of Cronbach Alpha for the five constructs in the actual study was between 0.813 and 0.940. Furthermore, the total value of Cronbach Alpha for the evaluation instrument of the pilot study and the actual study was 0.955 and 0.946 respectively. 
Significance - The self-evaluation instrument in learning geometry based on the CIPP model developed for this study was able to help students understand their level of mastery of the topics studied in Geometry. The students were helped in overcoming their shortcomings in the learning of Geometry. This self-evaluation instrument can be an important resource to assist teachers in designing learning strategies and to facilitate the more effective teaching of geometry topics. This self-evaluation instrument can also be used as a guide for determining the achievement of the learning outcomes of Form One Geometry.

Keywords: Self-evaluation instrument, learning geometry, validity and reliability, mathematics education.

\section{PENGENALAN}

Pendidikan matematik merupakan mata pelajaran yang mendidik pelajar memperkembangkan pemikiran mantik, analisis, kritis dan sistematik, kemahiran penyelesaian masalah dan kemahiran menggunakan ilmu pengetahuan matematik dalam kehidupan seharian (Abdul Razak Idris \& Nor Asmah Salleh, 2011). Untuk mencapai matlamat ini, maka proses pembelajaran dan pengajaran Matematik di sekolah perlu ditingkatkan. Menurut Noraini Idris (2001), ia memerlukan kurikulum yang mantap, pedagogi yang terkini dan sesuai dengan tahap kebolehan pelajar hari ini.

Penggunaan matematik telah bertambah dengan luasnya dalam semua lapisan masyarakat. Jika pada masa dahulu masyarakat hanya berpendapat bahawa matematik adalah untuk pengiraan sahaja, tetapi pada masa kini peranan yang dimainkan oleh matematik meliputi pelbagai jenis aktiviti seperti pemprosesan data, simulasi, membuat keputusan dan komunikasi yang dinyatakan oleh Noraini Idris (2001).

Pembelajaran geometri memberikan pengalaman dalam membantu pelajar memperkembangkan pemahaman terhadap sesuatu ciri, rupa dan bentuk. Semua aspek praktikal dan estetik geometri boleh ditemui dalam bidang seni dan pembinaan, penerokaan ruang, perancangan perumahan, serta rekaan fesyen dan kenderaan. Topik- 
topik ini sebenarnya memberikan persepsi yang berbeza kepada murid dan akan menarik minat mereka untuk melibatkan diri dengan ilmu geometri.

Selain itu, pembelajaran geometri membolehkan murid menyelesaikan masalah dan mengaplikasikannya dalam situasi dunia sebenar. Pembelajaran tentang konsep geometri dan penguasaan kemahiran menyelesaikan masalah geometri adalah penting dalam pendidikan matematik. Hubungkait alam sekeliling dengan ilmu geometri akan mengembangkan pengetahuan dan kemahiran geometri, kemahiran mevisualisasi ruang, atau boleh ditakrifkan sebagai celik ruang (spatial sense), serta keupayaan menyelesai masalah.

Teori perkembangan pembelajaran geometri ini telah dikemukakan oleh Pierre Marie van Hiele dan Dina van Hiele-Geldof, sepasang suami isteri dari Belanda yang telah banyak tahun mengkaji bagaimana kanak-kanak membentuk pemahaman terhadap Geometri Euclid (Van de Walle \& John, 2001). Menurut Van Hiele (1959), pembangunan teori pemikiran spatial dalam geometri mendorong pemahaman serta kemahiran murid dengan arahan-arahan yang menjurus kepada aras-aras pemikiran semulajadi geometri murid. Teori beliau mempunyai aras pemikiran bermula pada usia awal kanak-kanak sehinggalah dewasa.

Kini teori van Hiele telah diguna pakai oleh ramai pendidik matematik di kebanyakan negara bagi mengatasi kesukaran murid-murid dalam proses kognitif peringkat tinggi, terutama dalam pembuktian untuk mencapai penyelesaian khususnya pembelajaran geometri. Seperti yang dinyatakan oleh Van de Walle dan John (2001, m.s. 309) iaitu "[t]oday, the van Hiele theory has become the most influential factor in the American geometry curriculum."

Teori van Hiele yang dipostulasikan oleh pasangan Pierre dan Dina van Hiele pada 1957 terdiri dari tiga komponen utama, iaitu tahap pemikiran geometri, ciri-ciri tahap pemikiran geometri dan fasa pembelajaran. Walau bagaimana pun, mereka telah menamakan lima peringkat pemahaman geometri iaitu Tahap 0 (visualisasi), Tahap 1 (Analisis), Tahap 2 (Deduksi tak formal), Tahap 3 (Deduksi Formal) dan Tahap 4 (Pembuktian). Setiap peringkat menunjukkan proses pemikiran yang digunakan oleh seseorang dalam belajar konsep geometri (Kartono, 2010). 
Di Malaysia, kandungan sukatan pelajaran Matematik KBSM merangkumi pengetahuan dan kemahiran daripada tiga bidang yang saling berkait iaitu Nombor, Bentuk dan Ruang, dan Perkaitan. (Pusat Perkembangan Kurikulum, 2003). Konsep matematik berkaitan bidang masing-masing selanjutnya diatur mengikut topik. Topik-topik ini diatur mengikut hierarki supaya konsep yang lebih asas dan ketara diperkenalkan dahulu diikuti dengan konsep yang lebih kompleks dan abstrak.

Menurut Pusat Perkembangan Kurikulum (2003) dalam Sukatan Pelajaran Matematik, skop bentuk dan ruang merupakan suatu komponen penting dalam kurikulum matematik sekolah menengah. Pengetahuan dan kemahiran dalam bidang ini serta perkaitannya dengan topik-topik lain adalah berguna dalam situasi harian. Topik Geometri merupakan tajuk yang mula diajar di Tingkatan 1 iaitu pada peringkat menengah rendah. Konsep yang diajar pada peringkat ini merupakan konsep asas yang perlu dikuasai sebelum belajar konsep selanjutnya di tingkatan seterusnya. Antara topik-topik yang berkaitan dengan geometri yang diajar di sekolah menengah pada tahap menengah rendah ialah Poligon I \& II (Tingkatan 1 dan 2), Perimeter dan Luas (Tingkatan 1), Pepejal Geometri I, II \& III (Tingkatan 1, 2 dan 3), Pembinaan Geometri (Tingkatan 2), Bulatan I \& II (Tingkatan 2 dan 3) dan Penjelmaan I \& II (Tingkatan 2 dan 3).

\section{LATAR BELAKANG KAJIAN}

Kejayaan sesuatu sistem pendidikan dinilai melalui tahap pembelajaran dan perkembangan murid semasa mereka melalui sistem tersebut. Hasil pengajaran dan pembelajaran yang optimum dibentuk oleh tiga elemen iaitu pengajaran yang dijalankan oleh guru, pentaksiran ke atas murid dan pembelajaran murid itu sendiri (Mohd Faizal Nizam Lee, 2014). Menurut Noor Azreen Abd Aziz dan Sulaiman Yamin (2012), pelbagai usaha telah dijalankan bagi memperbaiki, mempertingkatkan dan memperkasakan sistem pendidikan Malaysia. Sistem Pentaksiran Pendidikan Kebangsaan (SPPK) adalah satu sistem pentaksiran yang diperkenalkan dalam transformasi pendidikan. Menurut Pelan Pembangunan Pendidikan Malaysia (PPPM) 2013-2025, sistem peperiksaan sedia ada 
dikembangkan kepada sistem Pentaksiran Berasaskan Sekolah (PBS). PBS lebih bersifat holistik, seimbang, fleksibel, adil dan merujuk kepada standard yang telah ditetapkan.

Dalam usaha melonjakkan sistem pendidikan negara, Kementerian Pelajaran Malaysia melaksanakan kurikulum baru untuk sekolah menengah iaitu Kurikulum Standard Sekolah Menengah (KSSM) pada tahun 2017. Kurikulum baru ini dirangka berdasarkan tanda aras antarabangsa bagi memastikan murid yang dilahirkan oleh sistem persekolahan di negara ini memiliki kemahiran yang diperlukan untuk bersaing di peringkat global. Ia merangkumi dimensi intelek, emosi dan fizikal setiap murid serta menekankan aplikasi pengetahuan serta perkembangan pemikiran kritis, kreatif dan inovatif.

Pencapaian geometri dalam matematik murid sekolah menengah rendah di Malaysia adalah kurang memuaskan berbanding dengan pelajar sekolah menengah rendah di negara-negara Asia Pasifik dalam kajian Trend International Mathematics and Science Study (TIMSS) yang melibatkan murid Tingkatan Dua (gred 8) di 150 buah sekolah yang dipilih secara rawak pada tahun 1999, 2003, 2007 dan 2011 (Pelan Pembangunan Pendidikan Malaysia 2013-2025). Laporan TIMSS 2011 menunjukkan penurunan prestasi Malaysia dari segi kedudukan untuk subjek Matematik iaitu 16 (1999), 10 (2003), 20 (2007) dan 26 (2011) dengan penurunan markah purata sebanyak 79 mata bagi subjek Matematik iaitu 519 (1999), 508 (2003), 474 (2007) ke 440 (2011). Penilaian markah di bawah 500 dikira sebagai prestasi corot (Pelan Pembangunan Pendidikan Malaysia 2013 -2025).

Prestasi Malaysia yang kurang memuaskan menunjukkan bahawa murid-murid tersebut kekurangan kebolehan berfikir dan menaakul pada tahap yang lebih tinggi. Keadaan ini juga berlaku pada murid negara maju seperti US, China, Belanda dan Singapura mempunyai tahap pencapaian yang rendah dalam soalan geometri berdasarkan laporan TIMSS 2007. Usiskin (1987) pernah menyatakan bahawa daripada semua murid berdaftar di sekolah tinggi di Amerika Syarikat hanya $63 \%$ boleh mengenal pasti pelbagai jenis segi tiga dengan betul dan $30 \%$ boleh membuat pembuktian. Selain itu, Penilaian Kemajuan Pendidikan Nasional (National Assessment of 
Educational Progress (NAEP), 2009) melaporkan bahawa murid US Gred 4 dan Gred 8 mempunyai keupayaan yang rendah dalam menguasai konsep asas geometri. Dapatan NAEP juga mendedahkan bahawa pelajar Gred 4 berada pada tahap rendah dalam mengenal pasti gambar mengikut keterangan dan sangat rendah dalam pengecaman segi tiga kongruen. Pelajar Gred 8 mengalami kesulitan mengenal pasti keputusan gabungan dua bentuk dan berada dalam kedudukan bawah dalam bidang pemodelan situasi geometri pada keadaan yang tertentu (Lee, Grigg \& Dion, 2007).

Tetapi, laporan TIMSS 2015 menunjukkan bahawa Malaysia mencatatkan peningkatan memberangsangkan dan berada pada kedudukan pertengahan antara 39 negara peserta berbanding TIMSS 2011. Berdasarkan laporan itu, Malaysia berjaya memperbaiki kedudukan bagi subjek Matematik pada tempat ke-22 dengan skor 465 mata, meningkat empat tangga berbanding pada TIMSS 2011 dengan kedudukan ke-26 (440 mata). Malaysia merupakan antara 18 negara yang menunjukkan peningkatan pencapaian iaitu 25 markah berbanding TIMSS 2011.

Menurut Mokthar Ismail(2009), penilaian dan pentaksiran merupakan komponen penting dalam proses pembelajaran dan pengajaran. Hasil dapatan penilaian dan pentaksiran dapat memberi maklumat kepada pendidik tentang keberkesanan pendekatan, strategi atau teknik pengajaran yang digunakan. Bagi seorang murid pula, ia merupakan satu indikator atau penunjuk kepada apa yang telah mereka pelajari, apa yang masih perlu dipelajari dan bagaimana cara terbaik untuk mempelajari sesuatu mata pelajaran. Di samping itu, bagi pihak ibu bapa, ia dapat memberi panduan tentang bagaimana cara terbaik untuk memberi sokongan dan dorongan kepada anak-anak mereka. Perubahan ini diharapkan dapat mengurangkan penekanan kepada pengajaran untuk peperiksaan.

Penilaian kendiri boleh ditakrifkan sebagai murid menilai kerja mereka sendiri berdasarkan bukti dan kriteria yang jelas bagi tujuan meningkatkan prestasi masa depan (Daniel, 2010). Ramai penyelidik bersetuju bahawa pelaksanaan murid membuat penilaian kendiri dalam bilik darjah adalah satu alat yang penting bagi meningkatkan prestasi akademik dan kemampuan. Daniel (2010) telah mengkaji penggunaan penilaian kendiri ke atas kumpulan murid yang 
terbahagi kepada dua kumpulan di mana satu kumpulan murid akan menggunakan rubrik untuk menilai hasil kerja sendiri manakala satu kumpulan lagi tidak. Hasil kajian menyakinkan empat hujah seperti yang dinyatakan oleh Rolheiser dan Ross (2001). Mereka menyatakan bahawa pembelajaran murid bertambah baik dengan adanya penilaian kendiri kerana menepati objektif pembelajaran yang hendak diukur, guru mendapat maklumat yang mencukupi dalam penilaian sesuatu tajuk, murid akan menumpukan perhatian kepada objektif yang diukur dan motivasi murid dapat dipertingkatkan. Hujah-hujah ini juga disokong oleh Black dan William (1998) yang menekankan kepentingan penilaian kendiri membolehkan murid memahami tujuan pembelajaran mereka dan mengetahui apa yang mereka perlu mencapai.

Penglibatan murid dalam penilaian mereka sendiri boleh menambah refleksi dan metakognitif kepada proses pembelajaran (Gunawardena Egodawatte, 2010). Berdasarkan pernyataan ini, instrumen penilaian telah dibangunkan bagi pelajar kolej untuk menilai sendiri terhadap penyelesaian masalah matematik. Instrumen penilaian mengandungi tiga item iaitu pendapat pelajar terhadap soal selidik, penilaian rubrik analitik dan jadual penilaian sendiri. Komponen penilaian rakan sebaya juga dilibatkan dalam proses penilaian untuk tujuan ketepatan penilaian. Melalui kajian ini, pelajar boleh menggunakan rubrik sebagai alat pembelajaran manakala guru menjadikan ia sebagai alat mengajar.

Rubrik dapat membantu guru menganalisis dan menghuraikan jawapan pelajar bagi tugas yang kompleks dan menentukan tahap kemahiran murid. Di samping itu, rubrik memberi kriteria yang lebih khusus kepada murid mengenai apa objektif yang diharapkan. Meier et al. (2006) melaporkan satu kajian di mana guru sekolah menengah menggunakan rubrik ke atas murid Gred 8 untuk menilai tugas mereka. Guru menggunakan rubrik pemarkahan analitik yang menggariskan tiga kategori untuk penilaian iaitu pengetahuan matematik, pengetahuan strategik dan penjelasan. Pengetahuan matematik adalah berkaitan dengan ketepatan matematik dan ketepatan istilah, manakala pengetahuan strategik adalah mengenal pasti masalah yang berlaku dan perbincangan mengenai caracara penyelesaian. Bagi kategori penjelasan pula, murid perlu menerangkan apa yang telah dilakukan, dan perbincangan mengapa 
ia dilakukan dengan penjelasan bertulis bagi gambar rajah atau jadual. Berdasarkan kajian-kajian yang dilaporkan, matlamat utama penilaian kendiri adalah untuk meningkatkan pembelajaran murid dan ia tidak akan digunakan untuk tujuan penggredan.

Pembinaan instrumen kajian ini berlatarbelakang kepada penerokaan dan pemahaman konsep geometri dalam kalangan murid sekolah menengah terutamanya Tingkatan Satu. Geometri merupakan salah satu topik yang penting dalam sukatan mata pelajaran matematik sekolah menengah (Pusat Perkembangan Kurikulum, 2003). Murid mula diperkenalkan dan didedahkan dengan geometri semenjak dari pendidikan tahap prasekolah lagi seperti yang dinyatakan oleh Noraini (2009). Kebiasaannya pengajaran geometri di sekolah rendah murid hanya diberi penekanan kepada mengenal pasti bentuk dan ciri sesuatu bentuk geometri melalui gambar rajah tanpa melibatkan konsep yang lebih kompleks di mana memerlukan pemahaman murid terhadap hubungan atau perkaitan antara bentuk dan ciri sesuatu geometri (Sukatan Pelajaran Kurikulum Standard Sekolah Rendah, 2010).

Pembelajaran geometri diberi penekanan kepada murid disebabkan sebanyak dua puluh empat topik daripada enam puluh topik matematik dalam kurikulum matematik sekolah menengah adalah mengandungi aspek geometri (KPM, 1998). Kefahaman dalam geometri dapat membekalkan pengalaman yang dapat membantu murid membina kefahaman terhadap bentuk, ruang, garisan serta fungsi setiap bentuk, ruang dan garisan tersebut. Ia membolehkan murid menyelesaikan masalah dan mengaplikasikannya dalam kehidupan seharian mereka.

\section{PERNYATAAN MASALAH}

Menurut Schuman (1991), pembelajaran geometri memberi pengalaman dalam membantu murid memperkembangkan pemahaman terhadap sesuatu ciri, rupa dan bentuk. Ia juga membolehkanmuridmenyelesaikanmasalahdanmengaplikasikannya dalam situasi dunia sebenar. Pembelajaran tentang konsep geometri dan penguasaan kemahiran menyelesaikan masalah adalah perkara penting di dalam pendidikan matematik. Kebolehan mengenal pasti 
sesuatu bentuk geometri, tidak bermakna bahawa murid tersebut menguasai tentang ciri-ciri asas sesuatu bentuk. Tanpa kefahaman ciri-ciri dan perkaitan antara ciri-ciri geometri yang mendalam, kesukaran murid-murid dalam pembelajaran geometri akan bertambah teruk di peringkat menengah atas kerana mereka akan belajar konsep-konsep geometri yang lebih sukar.

Menurut hasil kajian Mayberry (1981), kebanyakan pelajar mempelajari geometri di dalam bilik darjah secara hafalan. Kaedah sedemikian tidak memberi peluang kepada murid untuk terlibat dalam proses kemahiran berfikir bagi topik geometri. Malah, murid yang belajar secara menghafal cenderung untuk melupai maklumatmaklumat yang telah dihafal, keliru, ataupun tidak mampu untuk mengaplikasikan maklumat tersebut kepada situasi yang berbeza. Pengetahuan konsep adalah penting bagi murid apabila mereka mula belajar pembuktian (Aiso Heinze and Carl von Ossietzky, 2002). Kajian penemuan empirikal dengan 106 orang murid Gred 8 di sekolah menengah German menunjukkan bahawa terdapat kesukaran dalam pemahaman konsep quadrangles. Hal ini berlaku kerana pemahaman yang berbeza daripada pengkelasan quadrangles dan kesulitan dalam memahami bahasa matematik yang menyebabkan murid sukar dalam pembelajaran tajuk ini. Van de Sandt (2007, dalam Kakoma Luneta, 2014) mengakui bahawa geometri dianggap sebagai satu topik yang bermasalah di sekolah menengah di Afrika Selatan. Salah satu sebab utama adalah guru dan murid mempunyai pemahaman yang berbeza berdasarkan tahap pembelajaran Van Hiele. Justeru, berlakunya miskonsepsi geometri dalam pembelajaran murid. Selain itu, Aysen Ozerem (2012) melakukan kajian untuk mengenal pasti kelemahan murid sekolah menengah di Cyprus, Eropah dalam tajuk geometri iaitu sudut dan bentuk, penjelmaan dan pembinaan geometri. Hasil kajian mendapati murid mengalami miskonsepsi terhadap tajuk yang diuji dan murid mempunyai pengetahuan asas yang lemah.

Menurut kajian Noraini Idris (1999, dalam Noraini Idris, 2009), beliau menyatakan bahawa topik segi tiga dan sisi empat sebenarnya telah dipelajari bermula dari sekolah rendah hingga ke sekolah menengah. Oleh itu, murid sudah tentunya dapat mengenal pasti segi tiga dan sisi empat. Walau bagaimana pun, menerusi temu bual klinikal yang dilaksanakan oleh beliau ke atas murid-murid 
yang berumur 13 dan 14 tahun dari sekolah menengah di Selangor, didapati masih ada pelajar keliru dengan perbendaharaan kata iaitu "segi empat sama" dan "segi empat tepat".

Dalam kajian Saifulnizan Che Ismail (2007) pula menyatakan bahawa pembelajaran geometri memberikan pengalaman dalam membantu murid memperkembangkan pemahaman terhadap sesuatu ciri, rupa dan bentuk. Ia juga membolehkan murid menyelesaikan masalah dan mengaplikasikannya dalam situasi dunia sebenar. Pembelajaran tentang konsep geometri dan penguasaan kemahiran menyelesaikan masalah adalah perkara penting di dalam pendidikan matematik. Kebolehan mengenal pasti sesuatu bentuk geometri, tidak bermakna bahawa murid tersebut menguasai tentang ciri-ciri asas sesuatu bentuk. Kebiasaanya pengajaran geometri di sekolah menengah hanya memberi penekanan terhadap mengenal pasti bentuk dan ciri sesuatu bentuk geometri melalui gambar rajah tanpa melibatkan konsep yang lebih kompleks di mana memerlukan pemahaman pelajar terhadap hubungan atau perkaitan antara bentuk dan ciri sesuatu geometri.

Menurut kajian Siti Hajar Ramzan (2008), kajian beliau adalah untuk mengenal pasti corak kesilapan murid dalam pembelajaran topik "Sudut dan Garis" dalam Tingkatan 1. Antara aspek kemahiran dan konsep yang dikaji adalah terdiri daripada mendefinisi sudut, mengenal pasti jenis-jenis sudut, mengenal pasti jenis-jenis garisan, sudut pada garis lurus, sudut pada satu titik dan penyelesaian soalan masalah. Hasil dapatan kajian ini menunjukkan bahawa murid menghadapi masalah dengan soalan permasalahan matematik apabila melibatkan keupayaan murid mentafsir maklumat secara visual dan spatial. Murid tidak dapat mengaplikasikan maklumat daripada simbol-simbol matematik kepada bentuk ayat mudah dan ini mengakibatkan kesilapan pelajar dalam memilih teorem dan formula yang tepat dalam menyelesaikan soalan tersebut. Selain itu, penggunaan gambar rajah yang banyak dalam topik "Sudut dan Garis" ini merupakan masalah utama kepada murid dalam menyelesaikan soalan permasalahan.

Cagri Biber, Abdulkadir Tuna dan Samet Korkmaz (2013) mengkaji tahap pembelajaran, kesilapan dan miskonsepsi murid Gred 8 dalam tajuk Sudut dalam Geometri. Kajian ini dijalankan ke atas 
30 orang murid Gred 8 sekolah menengah yang terletak di tengah daerah utara wilayah Turki. Soalan terbuka digunakan dalam kajian ini. Daripada hasil kajian, murid memberi perhatian kepada bentuk fizikal sesuatu geometri tanpa mengambil kira sifat-sifat geometri. Walaupun mereka dapat mengesan beberapa sifat-sifat bentuk geometri, mereka masih tidak dapat mengaitkan sifat-sifat ini dengan ilmu lain untuk menyelesaikan masalah. Selain itu, murid membuat kesimpulan umum mengenai bentuk sesautu geometri dan tidak memahami sepenuhnya konsep sudut yang terbentuk daripada garis selari.

Sementara itu, Perimeter dan Luas merupakan salah satu topik yang diajar di dalam mata pelajaran Matematik Tingkatan 1. Dalam kajian Abdul Razak Idris dan Kevin (2011), murid banyak menghadapi masalah dalam pengiraan topik ini. Ini adalah kerana semua pengiraan melibatkan unit pengukuran. Murid tidak dapat menentukan unit yang berkaitan dengan pengiraan yang dibuat. Topik Perimeter dan Luas ini banyak melibatkan rajah dan unit ukuran. Menurut kajian yang dilakukan oleh penyelidik-penyelidik, terdapat lima kategori kesilapan murid. Antara yang paling ketara ialah murid tidak boleh menterjemah terutamanya dalam masalah rajah, masalah cerita dan masalah kreatif (Pusat Perkembangan Kurikulum, 2003).

Pernyataan di atas disokong oleh Reys, Suydam dan Lindquist (1995) dimana murid tidak dapat menyelesaikan masalah yang melibatkan rajah yang terdiri daripada beberapa bentuk yang berlainan. Selain itu, mengukur luas sesuatu objek boleh menjadi sukar jika murid itu sendiri tidak faham konsep Luas. Tambahan pula, Yudariah Mohammad Yusof et al. (2005) menyatakan bahawa kesalahan konsep atau kesukaran pembelajaran yang lazim dilakukan oleh murid ialah tidak mahir mengira luas segi tiga, segi empat, segi empat selari dan trapezium dengan rumus yang betul. Ini kerana murid tidak memahami dan mengetahui cara rumus tersebut dihasilkan. Menurut Leonard, Tipps dan Johnson (2004), murid sering keliru antara perimeter dan luas. Keadaan ini berlaku kerana kedua-dua konsep ini selalu diajar bersama-sama menyebabkan murid sering tertukar maksud perimeter dan luas. Walaupun keduadua konsep ini mempunyai perbezaan yang ketara, pengajaran tentang konsep ini seharusnya diajar dengan lebih berhati-hati supaya tidak menimbulkan kekeliruan pada murid. 
Pelbagai kajian berbentuk penilaian telah dilaksanakan bagi membantu guru dalam pengajaran dan pembelajaran geometri. Misalnya penggunaan bahan pengajaran dan pembelajaran berbantukan komputer seperti perisian Geometer's Sketchpad (GSP) bagi proses pengajaran dan pembelajaran tajuk Pepejal Geometri, Penjelmaan, Pembinaan Geometri dan Bulatan. Azlina Mohd Kosnin dan Suhaila Abdullah (2008) serta Lok (2008) menyatakan bahawa melalui penggunaan perisian GSP, tahap keupayaan visualisasi murid dan tahap pencapaian murid dalam tajuk geometri dapat ditingkatkan. Instrumen yang digunakan ialah ujian penilaian tahap pencapaian murid, soal selidik, pemerhatian pengajaran pembelajaran dan temu bual dengan guru-guru matematik. Selain itu, Siti Hajar Ramzan (2008) telah menggunakan set ujian topikal matematik sebagai instrumen kajian beliau dalam mengenal pasti corak kesilapan murid dalam pembelajaran topik "Lines and Angles" Tingkatan Satu dan Tiga. Tambahan pula, dalam sistem PBS, guru menggunakan instrumen seperti ujian topikal untuk menilai kefahaman dan kemahiran murid. Kemudiannya pencapaian murid direkod oleh guru yang mengajar dalam Modul Perekodan Perkembangan Pembelajaran Murid berdasarkan Panduan Perkembangan Pembelajaran Murid yang telah ditetapkan oleh KPM.

Penyelidik mendapati adalah sukar untuk mendapatkan satu instrumen yang khusus bagi murid dalam menilai diri sendiri dari segi pencapaian, kemahiran dan kefahaman mereka dalam pembelajaran geometri. Kebanyakkan penilaian terhadap pencapaian murid dinilai oleh guru mata pelajaran mereka.

Dalam proses pembelajaran dan pengajaran, murid merupakan penilai terbaik terhadap pembelajaran mereka (Mohammad Najib Abdul Ghafar, 2011). Pembelajaran kendiri membolehkan murid lebih mengetahui dan berjaya dalam apa yang mereka pelajari (Mohd Faizal Nizam Lee, 2015). Guru tidak mungkin akan mengetahui apa yang murid benar-benar tahu atau berupaya mengetahui. Namun, kadang-kadang murid itu sendiri juga tidak mengetahui keupayaan sendiri tanpa membuat refleksi, pertimbangan dan penilaian. Dengan adanya instrumen penilaian kendiri ini, ia membolehkan murid menilai dan seterusnya mengenal keupayaan diri sendiri. 
Justeru, kajian ini wajar dijalankan sebagai satu usaha untuk membina satu instrumen di mana yang memberi peluang kepada murid untuk menilai sendiri kefahaman mereka terhadap pembelajaran topik geometri setelah diajar oleh guru mereka.

\section{OBJEKTIF KAJIAN}

Secara khususnya, objektif kajian ini ialah untuk:

(i) Membina instrumen penilaian kendiri pembelajaran geometri bagi murid Tingkatan Satu.

(ii) Menentukan kesahan dan kebolehpercayaan instrumen penilaian kendiri pembelajaran geometri Tingkatan Satu.

\section{MODEL PENILAIAN}

Model penilaian KIPP yang dikemukakan oleh Stufflebeam (1971) adalah berasaskan kepada empat jenis maklumat penilaian iaitu penilaian konteks, input, proses dan produk yang diperlukan oleh penggubal dasar dan pentadbir untuk membuat keputusan.

Model penilaian KIPP telah digunakan untuk menilai pelbagai program pendidikan (Zhang, Griffith et al. (2009) dan Zhang, Zeller, et al. (2008). Felix (1979) menggunakan model KIPP untuk menilai dan memperbaiki sistem arahan di sekolah bagi wilayah Cincinnati. Manakala Ohio \& Nicholson (1989) mencadangkan model penilaian KIPP untuk menilai proses membaca arahan di sekolah. Matthews dan Hudson (2001) menyediakan garis panduan bagi penilaian projek-projek latihan ibu bapa dalam rangka Model penilaian KIPP. Di Amerika Syarikat, fakulti pembangunan menggunakan Model KIPP untuk menyokong pengajaran dan penilaian profesionalisme pelajar-pelajar perubatan di sana (Steinert, Cruess, Cruess, \& Snell, 2005). Selain itu, Model KIPP digunakan untuk membina sistem petunjuk pendidikan kebangsaan Taiwan (Chien, Lee, \& Cheng, 2007).

Beberapa penyelidik di Malaysia telah menggunakan model KIPP untuk menilai keberkesanan pengajaran dan pembelajaran. 
Noorshafina Ibrahim (2009) dalam kajiannya bertajuk keberkesanan program latihan mengajar dalam menyediakan guru-guru pendidikan teknikal berdasarkan model KIPP. Seramai 127 pelajar daripada Pendidikan Teknikal dan Kejuruteraan dipilih sebagai responden secara persampelan rawak mudah. Kajian rintis dijalankan untuk melihat kebolehpercayaan dan kesesuaian soal selidik. Dapatan kajian menunjukkan terdapat hubungan yang signifikan antara pengetahuan, kemahiran, pengalaman, kemahiran generik, keyakinan, pencapaian dan sikap dengan pencapaian latihan mengajar. Beliau juga mengemukakan cadangan dalam usaha untuk memperbaiki terhadap keberkesanan latihan mengajar dalam menyediakan guru-guru pendidikan teknikal berdasarkan model KIPP. Melalui penilaian kendiri, guru pelatih dapat mengetahui kekuatan dan kekurangan yang boleh diperbaiki semasa dalam latihan mengajar.

Sidek Said dan Ahmad Rahim (2010) telah menjalankan kajian untuk menilai pelaksanaan kurikulum Sejarah Menengah Rendah dengan menggunakan model penilaian KIPP. Sampel kajian merangkumi 147 orang guru dan 1441 orang pelajar menengah rendah. Kajian ini menggunakan instrumen soal selidik bagi menilai dimensi input, proses dan produk. Dapatan kajian menunjukkan pandangan guru terhadap konstruk pengetahuan pedagogi, kemudahan prasarana, perancangan pengajaran dan pembelajaran berada pada tahap sederhana manakala skor min pemantauan kurikulum pula berada pada tahap rendah. Bagi pandangan pelajar, semua konstruk yang diukur memperlihatkan nilai min pada tahap yang sederhana bagi dimensi input, proses dan produk. Implikasi kajian ini adalah untuk mencapai keberkesanan pelaksanaan kurikulum Sejarah. Guru perlu melaksana pembelajaran aktif dalam bilik darjah. Program latihan guru Sejarah perlu dipertingkatkan lagi dan konsep 'retraining' perlu diberi penekanan. Bahan bantu mengajar untuk guru-guru sejarah juga perlu diperbanyakkan.

Selain itu, Ila Husna (2015) menjalankan kajian penilaian kendiri guru matematik sekolah rendah mengenai persekitaran pembelajaran maya (VLE FROG). Tujuan kajian ini adalah untuk menilai sejauh mana elemen-elemen konteks, input dan proses mempengaruhi produk iaitu tahap penggunaan VLE Frog dalam pembelajaran dan 
pengajaran matematik sekolah rendah. Kajian ini dijalankan untuk melihat penilaian kendiri guru matematik terhadap VLE Frog di Daerah Manjung, Perak yang melibatkan 120 responden dengan menggunakan Model KIPP. Selain itu, ia bertujuan mengenal pasti usaha bagi meningkatkan penggunaan VLE Frog dalam pengajaran dan pembelajaran matematik. Hasil kajian mendapati penilaian kendiri guru dalam konteks, input, dan proses pelaksanaan VLE Frog masih kurang memberangsangkan dan belum mencapai matlamat yang diharapkan di mana tahap penggunaan dan kesesuaian VLE Frog yang masih rendah dalam penilaian produk. Implikasinya, didapati penilaian kendiri guru matematik terhadap VLE Frog dalam penilaian konteks, input, proses dan produk Model CIPP masih memerlukan penambahbaikan.

Di dalam kajian ini, Penilaian "konteks" tertumpu kepada persekitaran iaitu perubahan akan berlaku dan masalah persekitaran yang dihadapi sepertimana yang dinyatakan dalam pernyataan masalah. Penilaian "input" pula tertumpu kepada sumber yang terlibat dalam membina instrumen penilaian murid dalam pembelajaran geometri. Hasil daripada tinjauan literatur yang dilakukan, terdapat lima konstruk utama dijadikan sebagai tunjang kepada kajian ini. Antaranya, pengetahuan sedia ada murid, kefahaman murid dalam geometri, gaya pembelajaran murid, sikap pembelajaran murid dan pendekatan pengajaran guru. Penilaian "proses" tertumpu kepada proses yang dijalankan untuk membina instrumen penilaian. Item-item penilaian dibina berdasarkan konstruk-konstruk yang telah ditetapkan. Manakala, penilaian "produk" tertumpu kepada penghasilan instrumen penilaian murid terhadap pembelajaran geometri Tingkatan Satu yang mempunyai kesahan dan kebolehpercayaan yang memuaskan.

Penyelidik telah mengadaptasi model KIPP ini untuk membina satu kerangka konseptual yang menggambarkan hubungan antara konteks-input-proses-produk. Rajah 1 menunjukkan kerangka konseptual yang digunakan dalam kajian ini. 


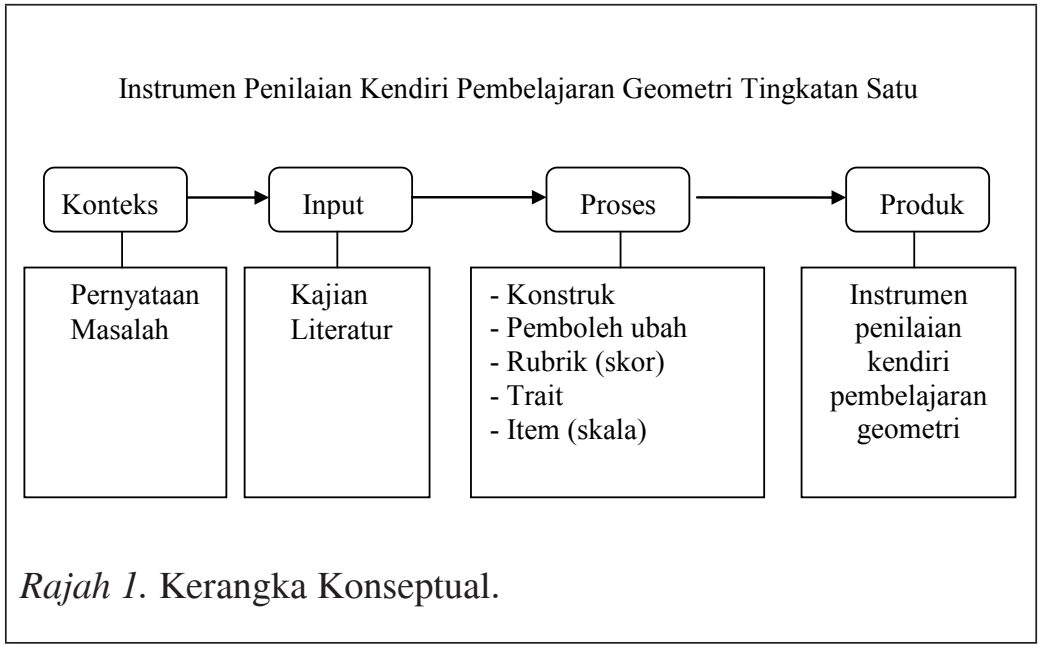

\section{KEPENTINGAN KAJIAN}

Penghasilan instrumen penilaian kendiri yang berpandukan Model KIPP dapat membantu murid membuat refleksi kendiri mengenai apa yang dia telah diajar dan dipelajari. Murid juga dapat mengetahui tahap penguasaannya terhadap topik-topik geometri yang dipelajari selama ini dan seterusnya berusaha untuk membaiki kelemahan-kelemahan dalam pembelajaran topik geometri Tingkatan Satu.

Instrumen penilaian ini juga boleh dijadikan sebagai sumber rujukan guru dalam membantu perancangan strategi pembelajaran dan pengajaran topik geometri yang lebih berkesan Hasil dapatan kajian membolehkan guru lebih memahami dan mengetahui tahap pemahaman dan penguasaan murid mereka dalam topik geometri. Mereka juga dapat mengenal pasti masalah yang mungkin dialami semasa sesi pengajaran.

Adalah diharapkan instrumen penilaian kendiri dijadikan sebagai panduan bagi melihat sejauh manakah hasil pembelajaran bagi topik Geometri Tingkatan Satu telah tercapai dengan optimum bersesuaian dengan sasaran dan tujuan pembelajaran itu sendiri. 


\section{METODOLOGI}

\section{Reka Bentuk Kajian}

Kajian ini adalah untuk membina dan menghasilkan instrumen penilaian murid terhadap pembelajaran geometri Tingkatan Satu. Kajian ini merupakan penyelidikan tinjauan yang bertujuan untuk menerangkan atau meramal sesuatu fenomena yang sedang berlaku (Khalid, 2003). Menurut Baharuddin et al. (2002), penggunaan instrumen merupakan kaedah yang berkesan dan menyediakan maklumat dalam bentuk kuantitatif daripada sesuatu kaji selidik yang lebih umum. Nilai sesuatu maklumat yang diperolehi daripada proses penilaian instrumen bergantung kepada betapa sempurnanya sesuatu instrumen tersebut direka bentuk (Lu, 2004). Item-item yang dikemukakan seharusnya tepat dan tidak mengarah kepada pemberian jawapan yang pelbagai sehingga sukar dianalisis. Selain itu, penyelidikan tinjauan digunakan untuk memeriksa kefungsian item, kesahan dan kebolehpercayaan instrumen kajian melalui data item yang diperoleh (Syed Muhd Kamal, Ahmad \& Syed Muhamad Dawilah, 2014).

Kajian yang telah dijalankan terbahagi kepada tiga fasa iaitu analisis kajian literatur, pembinaan instrumen kajian serta pengesahan dan menentukan kebolehpercayaan instrumen kajian yang dibina. Gabungan ketiga-tiga fasa tersebut menghasilkan instrumen penilaian kendiri pembelajaran geometri Tingkatan Satu yang mempunyai kesahan dan kebolehpercayaan.

\section{Fasa 1: Analisis Kajian Literatur}

Tinjauan literatur yang berkaitan dengan pembelajaran murid dalam bidang geometri menengah rendah dilakukan untuk mengenal pasti konstruk-konstruk yang merupakan elemen penting dalam pembinaan instrumen penilaian kendiri murid terhadap pembelajaran geometri Tingkatan Satu. Lima konstruk utama yang dikenal pasti ialah pengetahuan sedia ada murid, kefahaman murid dalam tajuk Geometri Tingkatan Satu, gaya pembelajaran murid, sikap pembelajaran murid dan pendekatan pengajaran guru. Berikut merupakan huraian ringkas bagi konstruk-konstruk dalam instrumen penilaian kendiri ini. 


\section{Pengetahuan Sedia Ada}

Pengetahuan sedia ada pelajar merupakan asas penting dalam mempercepatkan proses mempelajari sesuatu ilmu yang baru. Menurut Suppiah Nachiappan et al. (2009), pengalaman yang sedia ada dalam diri seseorang murid menjadi faktor utama mempengaruhi kesediaan murid untuk menerima pengajaran yang disampaikan oleh guru. Ini menjadi prinsip asas kepada penentu kejayaan sesuatu proses pembelajaran dan pengajaran. Sesetengah guru menghadapi kesukaran dalam melaksanakan pengajaran kerana isi pelajaran yang disampaikan itu berada di luar pengalaman murid. Namun begitu, setelah murid memperoleh pengalaman, secara tidak langsung pengalaman inilah yang membantu murid dengan mudah menguasai isi pelajaran yang disampaikan oleh guru. Pembelajaran ilmu geometri bermula dengan pengetahuan atau pengalaman sedia ada murid. Jadi murid haruslah memahami konsep geometri yang paling asas iaitu pengetahuan tentang bentuk-bentuk 2 dimensi dan 3 dimensi sehingga konsep geometri yang lain.

\section{Kefahaman Murid dalam Geometri}

Menurut Pusat Perkembangan Kurikulum (2003), kefahaman yang jelas tentang topik geometri atau bentuk dan ruang dapat mengekalkan pengalaman yang dapat membantu murid membina kefahaman terhadap bentuk, ruang, garisan serta fungsi setiap bentuk, ruang dan garisan tersebut. Ia membolehkan murid menyelesaikan masalah dan mengaplikasikannya dalam kehidupan seharian mereka. Kefahaman geometri yang diukur dalam kajian ini adalah berdasarkan sukatan pelajaran matematik Tingkatan 1 .

\section{Gaya Pembelajaran Murid}

Gaya pembelajaran merupakan pendekatan atau cara bagaimana seseorang itu belajar dalam memperolehi ilmu pengetahuan, kemahiran dan sikap yang positif (Ee, 2003). Gaya pembelajaran seseorang itu adalah bebas mengikut kemampuan individu tersebut dan ia mestilah memuaskan keperluan individu itu sendiri sehingga beliau mencapai tahap kefahaman yang diinginkan (Meor Ibrahim dan Assaadah, 2011). Model gaya pembelajaran Dunn dan Dunn 
(1978) telah dipilih dalam pelaksanaan kajian ini. Menurut Dunn dan Dunn (1978), gaya pembelajaran seseorang individu itu dapat disesuaikan mengikut gaya pembelajaran yang pelajar amalkan. Terdapat lima rangsangan dalam model ini iaitu persekitaran, emosional, sosiologikal, fisiologi dan psikologi.

\section{Sikap Pembelajaran Murid}

Pengertian sikap terlalu luas dan berbagai-bagai tetapi untuk kajian ini pengertian yang diberikan oleh Katz (1966, dalam Azizi Yahaya, Jamaluddin Ramli \& Yusof Boon, 2010), sikap adalah sesuatu yang mempengaruhi seseorang individu di dalam memberi nilai terhadap simbol objek atau apa yang disukai atau tidak. Selain itu, sikap adalah sesuatu yang terhasil dari perasaan, kepercayaan atau pemikiran seseorang terhadap objek psikologi. Sikap juga boleh ditaksir sebagai apa yang kita sukai dan apa yang kita tidak sukai. Sikap menggambarkan kesediaan untuk melakukan sesuatu dan kepercayaan seseorang berkenaan sesuatu perkara. Oleh itu, penyelidik lebih berfokus kepada aspek sifat yang berkaitan rapat dengan motivasi, minat dan keyakinan.

\section{Pendekatan Pengajaran Guru}

Menurut Noraini Idris (2001), pengajaran yang berkesan memerlukan pemahaman yang mendalam terhadap proses pembelajaran, ciriciri pelajar yang berada pada tahap perkembangan yang berbeza dan faktor-faktor yang mempengaruhi motivasi. Seseorang guru biasanya bergantung kepada perkara-perkara tersebut apabila membuat keputusan tentang bagaimana dia hendak menyampaikan sesuatu pengajaran. Pemilihan strategi pembelajaran dan pengajaran yang efektif, pemilihan bahan bantu mengajar serta komunikasi yang berkesan sangat diperlukan bagi memastikan kejayaan sesuatu proses pengajaran.

Setelah menetapkan konstruk, penyelidik menentukan pemboleh ubah bagi setiap konstruk berdasarkan kajian literatur. Ciri-ciri atau trait bagi pemboleh ubah setiap konstruk berkenaan digunakan sebagai panduan untuk membina item-item bagi konstruk tersebut. Jadual 1 menunjukkan pemboleh ubah-pemboleh ubah bagi setiap konstruk berkenaan. 


\section{Jadual 1}

Senarai Pemboleh ubah dan Trait dalam Konstruk yang Ditetapkan

\begin{tabular}{lll}
\hline Konstruk & Pemboleh ubah & Trait \\
\hline Pengetahuan sedia & Pengetahuan & Definisi bentuk 2 dimensi dan 3 \\
ada & sekolah rendah & dimensi \\
& & Jenis bentuk 2 dimensi dan 3 dimensi \\
& Ciri-ciri bentuk 2 dimensi dan 3 \\
& dimensi \\
& Rumus bagi perimeter, luas dan \\
& isipadu
\end{tabular}

\begin{tabular}{lll}
\hline Kefahaman murid & Sukatan pelajaran & Sudut dan garis \\
dalam Geometri & tingkatan satu & Poligon \\
& & Perimeter dan luas \\
& Pepejal geometri
\end{tabular}

Gaya pembelajaran Persekitaran Suasana pembelajaran

murid

$\begin{array}{ll}\text { Emosional } & \text { Perasaan dan tindakan murid } \\ \text { Sosiologi } & \text { Cara pergaulan } \\ \text { Fizikal } & \begin{array}{l}\text { Pengamatan } \\ \text { Masa/ pergerakan }\end{array} \\ \text { Psikologi } & \begin{array}{l}\text { Global atau analitik, Otak kiri atau } \\ \text { otak kanan, impulsif atau reflektif }\end{array}\end{array}$

Sikap pembelajaran Motivasi Pemikiran positif

murid

\begin{tabular}{lll} 
& Minat & $\begin{array}{l}\text { Kesediaan belajar } \\
\text { Keutamaan kefahaman murid }\end{array}$ \\
& Keyakinan & $\begin{array}{l}\text { Yakin diri } \\
\text { Kecekapan }\end{array}$ \\
\hline $\begin{array}{l}\text { Pendekatan } \\
\text { pengajaran guru }\end{array}$ & $\begin{array}{l}\text { Strategi } \\
\text { pembelajaran dan } \\
\text { pengajaran }\end{array}$ & $\begin{array}{l}\text { Proses pembelajaran dan pengajaran } \\
\text { guru }\end{array}$ \\
& $\begin{array}{l}\text { Bahan bantu } \\
\text { mengajar (BBM) }\end{array}$ & $\begin{array}{l}\text { Penggunaan BBM } \\
\text { Bahan bercetak } \\
\text { Bahan bukan bercetak } \\
\end{array}$ \\
& $\begin{array}{l}\text { Perkakasan } \\
\text { komunikasi }\end{array}$ & Lisan \\
\hline
\end{tabular}




\section{Fasa 2: Pembinaan Instrumen Kajian}

\section{Instrumen kajian}

Setelah mengenal pasti dan menentukan konstruk dan pemboleh ubahnya, penyelidik menentukan bentuk item yang diguna pakai pada setiap konstruk tersebut. Item penilaian ini merupakan satu set siri pernyataan di mana ia hanya digunakan untuk pentaksiran kendiri responden berkenaan. Instrumen kajian yang digunakan adalah berbentuk rubrik dua lapis (Mohd Faizal Nizam Lee, 2014). Rubrik merupakan satu bentuk skema penskoran yang ditetapkan mengikut kriteria seperti daripada lemah ke cemerlang (KPM, 2012). Kriteria ini digunakan untuk membuat ranking atau pemeringkatan terhadap pencapaian murid. Menurut Moskal (2000), rubrik menjadikan sistem penskoran lebih mudah dipelajari dan digunakan serta pelajar dapat mengetahui tahap-tahap kualiti dalam skala bagi tujuan untuk meningkatkan lagi kemajuan yang perlu dicapai.

Dalam kajian ini, rubrik analitik dan holistik telah digunakan dalam pembinaan instrumen penilaian. Rubrik analitik digunakan dalam proses pembinaan item di mana setiap item penilaian mempunyai empat rubrik untuk diisikan skornya. Oleh itu, murid diminta mengisi skor bagi setiap rubrik terhadap setiap item yang dikemukakan. Bagi konstruk pengetahuan sedia ada dan kefahaman murid dalam geometri, penyelidik menggunakan skor rubrik iaitu bagi jawapan "Tidak" diberikan skor 0 dan jawapan "Ya" diberikan skor 1. Manakala, bagi konstruk gaya pembelajaran murid, sikap pembelajaran murid serta pendekatan pengajaran guru, penyelidik menggunakan skor rubrik iaitu bagi jawapan "Tidak" diberikan 0 , jawapan "Kadang-kala" diberikan skor 1 serta jawapan "Selalu" diberikan skor 2.

Untuk mentaksir satu gambaran secara keseluruhan bagi setiap konstruk yang dinilai oleh seseorang responden, maka rubrik holistik digunakan dalam Lembaran Permarkahan Kendiri yang diisi oleh responden setelah selesai melakukan set instrumen penilaian. Bagi konstruk pengetahuan sedia ada dan kefahaman murid dalam geometri, penyelidik berpandukan kepada skala lima mata iaitu 0-sangat lemah, 1-lemah, 2-sederhana, 3-baik dan 4-cemerlang supaya skor min yang diperoleh digunakan untuk menentukan 
tahap penguasaan topik geometri murid berkenaan. Manakala, bagi konstruk gaya pembelajaran murid, sikap pembelajaran murid serta pendekatan pengajaran guru, penyelidik berpandukan kepada skala lima mata iaitu 0-paling kurang, 1-kurang, 2-sederhana, 3-banyak dan 4-paling banyak supaya skor min yang diperoleh digunakan untuk menentukan pemboleh ubah manakah mempunyai pengaruh yang utama dalam konstruk.

Sebanyak 79 item telah dibina dalam instrumen penilaian ini. Bilangan dan pecahan item mengikut konstruk bagi instrumen ini ditunjukkan pada Jadual 2.

Jadual 2

Taburan Item Mengikut Konstruk dalam Instrumen Penilaian

\begin{tabular}{lcc}
\hline \multicolumn{1}{c}{ Konstruk } & Nombor Item & Bilangan Item \\
\hline Pengetahuan Sedia Ada & $1-12$ & 12 \\
Kefahaman Murid dalam Geometri & $13-42$ & 30 \\
Gaya Pembelajaran Murid & $43-58$ & 16 \\
Sikap Pembelajaran Murid & $59-67$ & 9 \\
Pendekatan Pengajaran Guru & $68-79$ & 12 \\
\hline \multicolumn{1}{c}{ Instrumen } & $1-79$ & 79 \\
\hline
\end{tabular}

\section{Membangunkan Jadual Spesifikasi Instrumen (JSI)}

Pembinaan Jadual Spesifikasi Instrumen (JSI) boleh menggelakkan penggubal penilaian daripada bersikap cuai seperti menulis soalan tanpa perancangan yang menyebabkan sebahagian konstruk sahaja diukur (Syed Muhd Kamal, Ahmad dan Syed Muhamad Dawilah, 2014). Justeru, penyelidik telah membina JSI untuk membantu dalam pembinaan item bagi instrumen penilaian kendiri pembelajaran geomteri Tingkatan Satu ini. Perincian JSI ini terdiri daripada konstruk, pemboleh ubah, penyoalan, trait, item dan skala (Mohd Sahandri Gani et al., 2013). Tambahan pula, JSI dirangka dengan mengambil kira konstruk, pemboleh ubah dan cara penyoalan bagi menghuraikan item dan rubrik. Kesemua langkah ini dipandu serta disokong oleh literatur yang bersesuaian (Mohd Faizal Nizam Lee et al., 2014). JSI mengandungi data penting mengenai isi ujian dan 
dengan itu boleh meninggikan lagi tahap keobjektifan dan kesahan kandungan (Mohd Najib, 1997). Selain itu, menurut Mohd Sahandri Gani et al. (2014), JSI merupakan suatu proses merancang dan membina item penilaian yang mengambil kira skor rubrik dan skala penilaian. Penyelidik telah mengenal pasti konstruk dan pemboleh ubah berkaitan daripada kerja-kerja oleh Abdul Halim et al., (2010) dan Syed Muhd Kamal, Ahmad dan Syed Muhamad Dawilah (2014) dan kemudiannya bertindak membentuk item dan trait berdasarkan setiap pemboleh ubah yang dikenal pasti. Setiap item mengandungi empat rubrik yang berbeza untuk menjawab soalan yang dikemukakan mengenai penilaian murid terhadap pembelajaran geometri Tingkatan Satu. Menurut Noraini (2010), item dalam soal selidik atau instrumen wajar selaras dengan umur dan perkembangan kognitif responden. Justeru, penyelidik telah membina item seberapa ringkas dan tepat yang mungkin bagi memudahkan memahaminya dan seterusnya menjawab item berkenaan. Jadual 3 menunjukkan contoh sebahagian pembentukan item bagi kelima-lima konstruk dalam JSI. Jadual 4 merupakan contoh pembentukan item dua jenis skor rubrik yang digunakan bagi instrumen kajian berbentuk dua lapis yang telah dibina dalam kajian ini. 


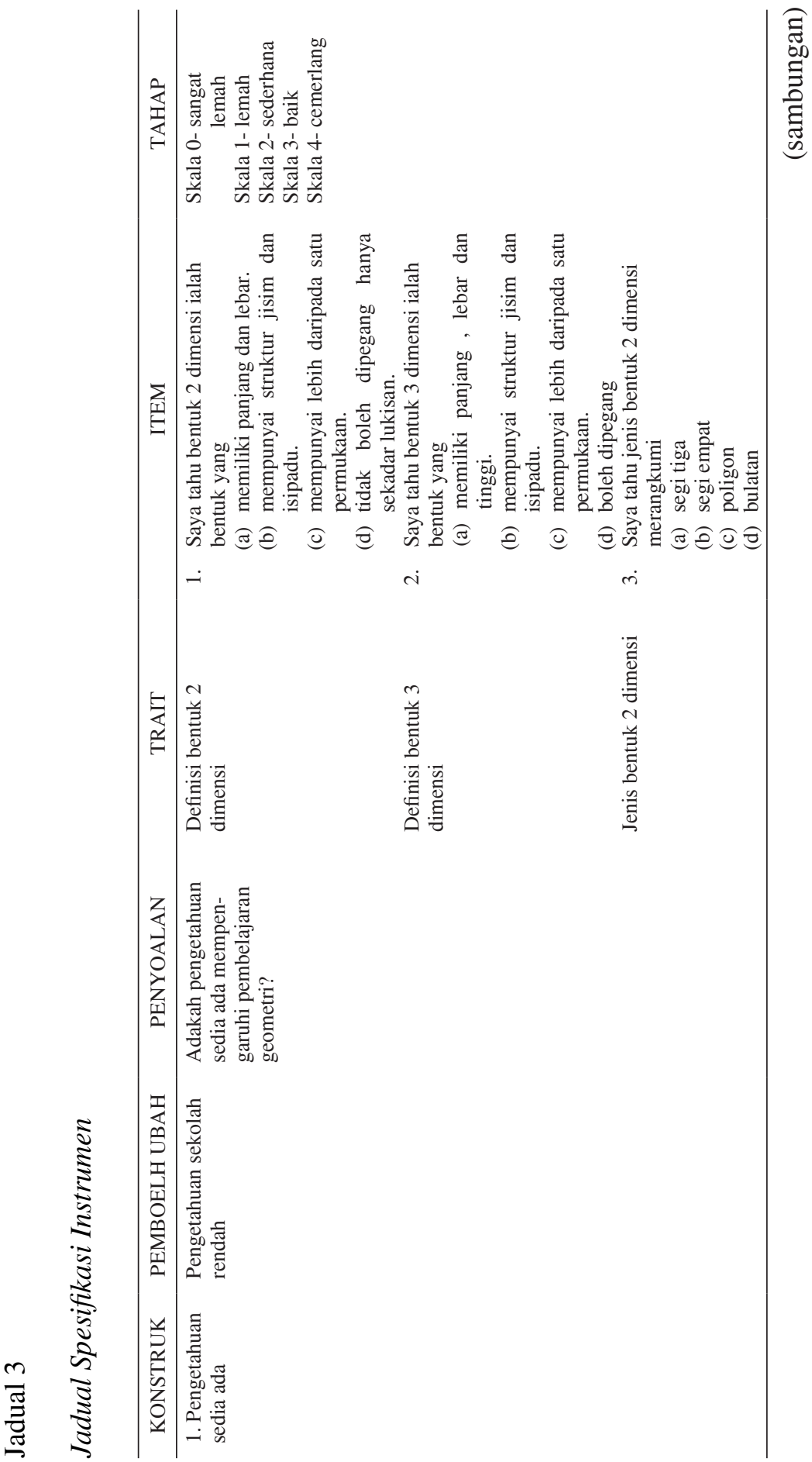




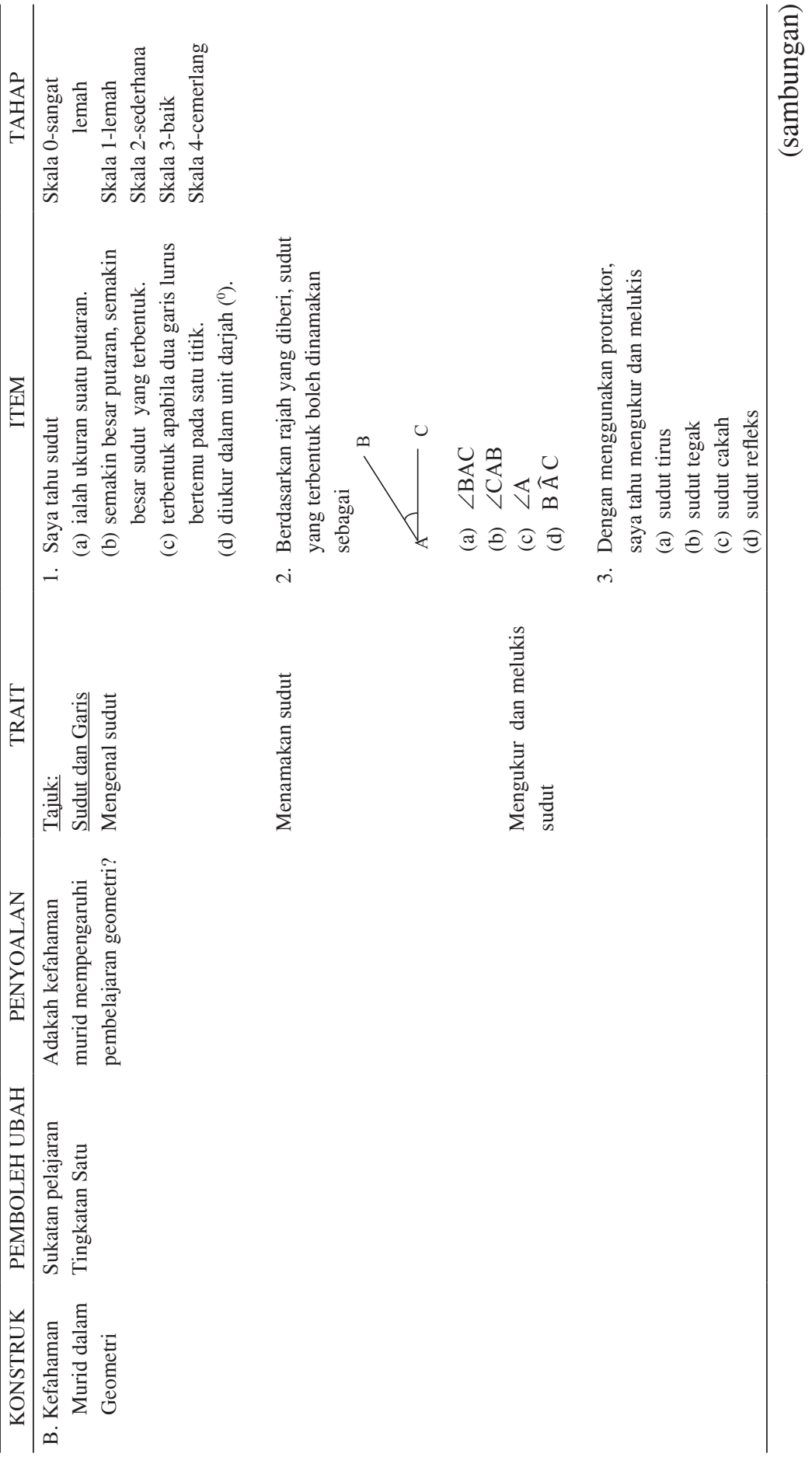



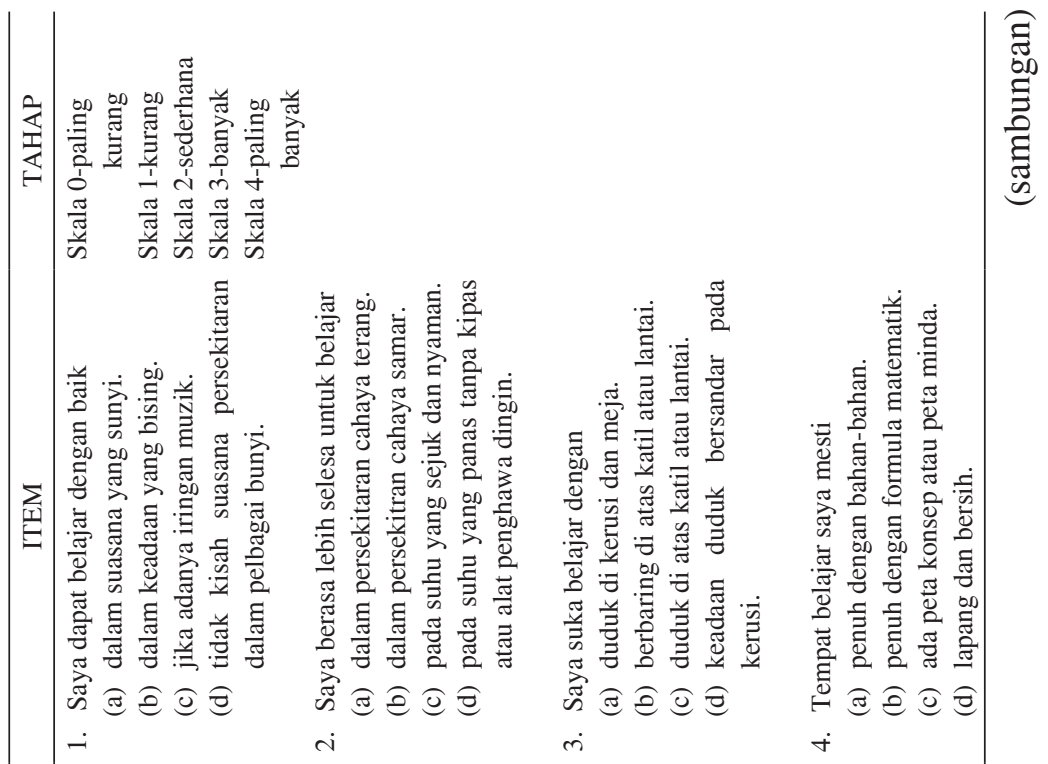

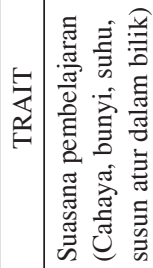

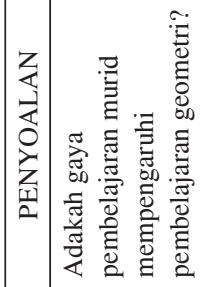

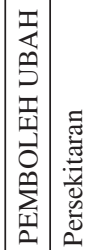

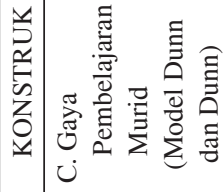




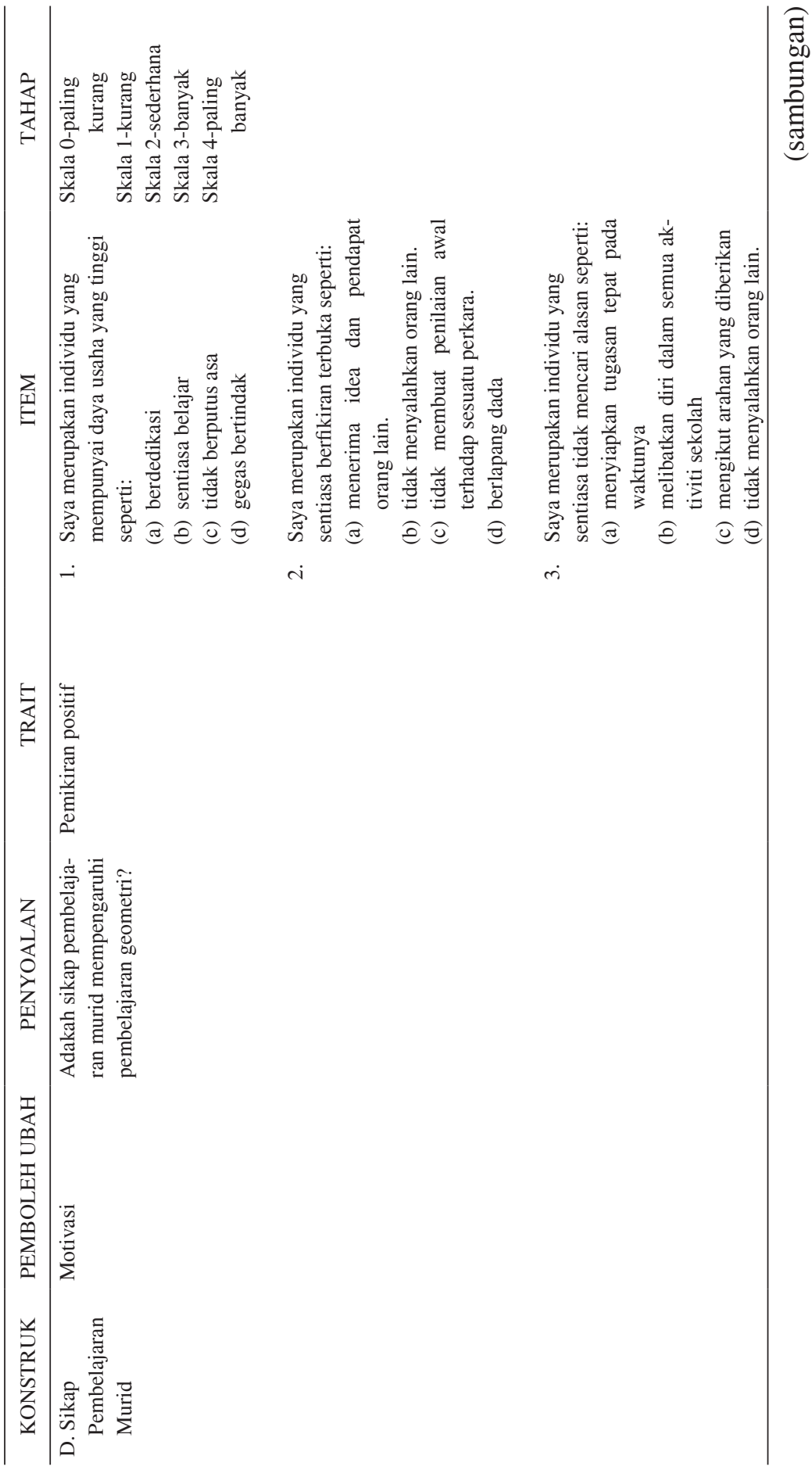




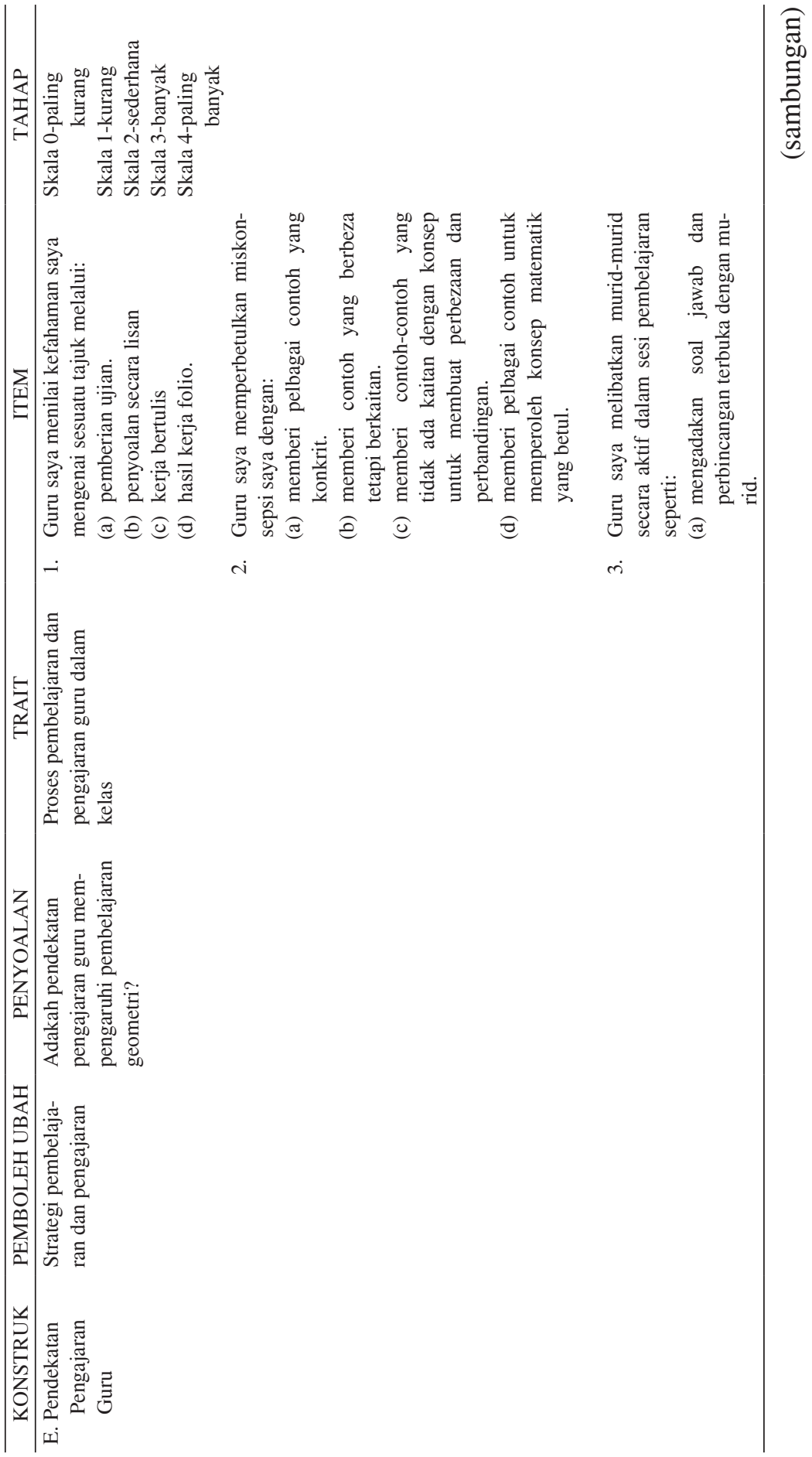




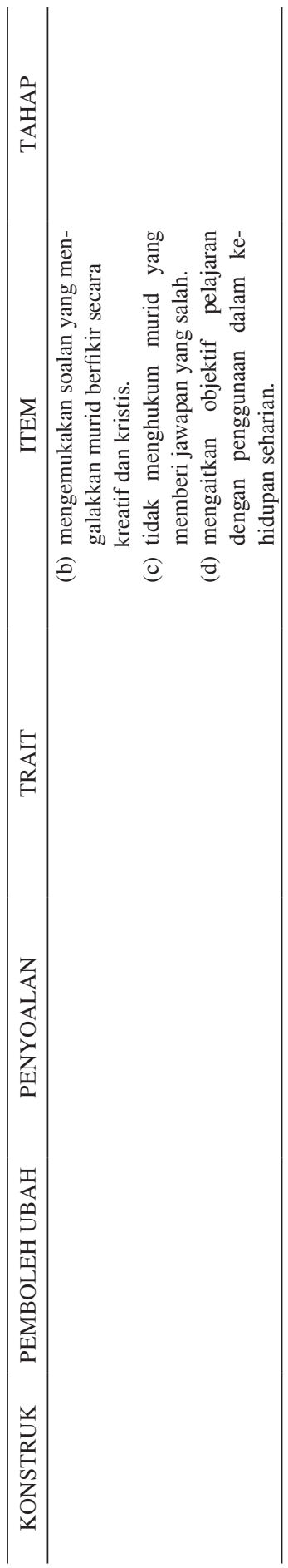




\section{Jadual 4}

\section{Contoh Instrumen Kajian Berbentuk Dua Lapis}

\section{Konstruk : Pengetahuan Sedia Ada}

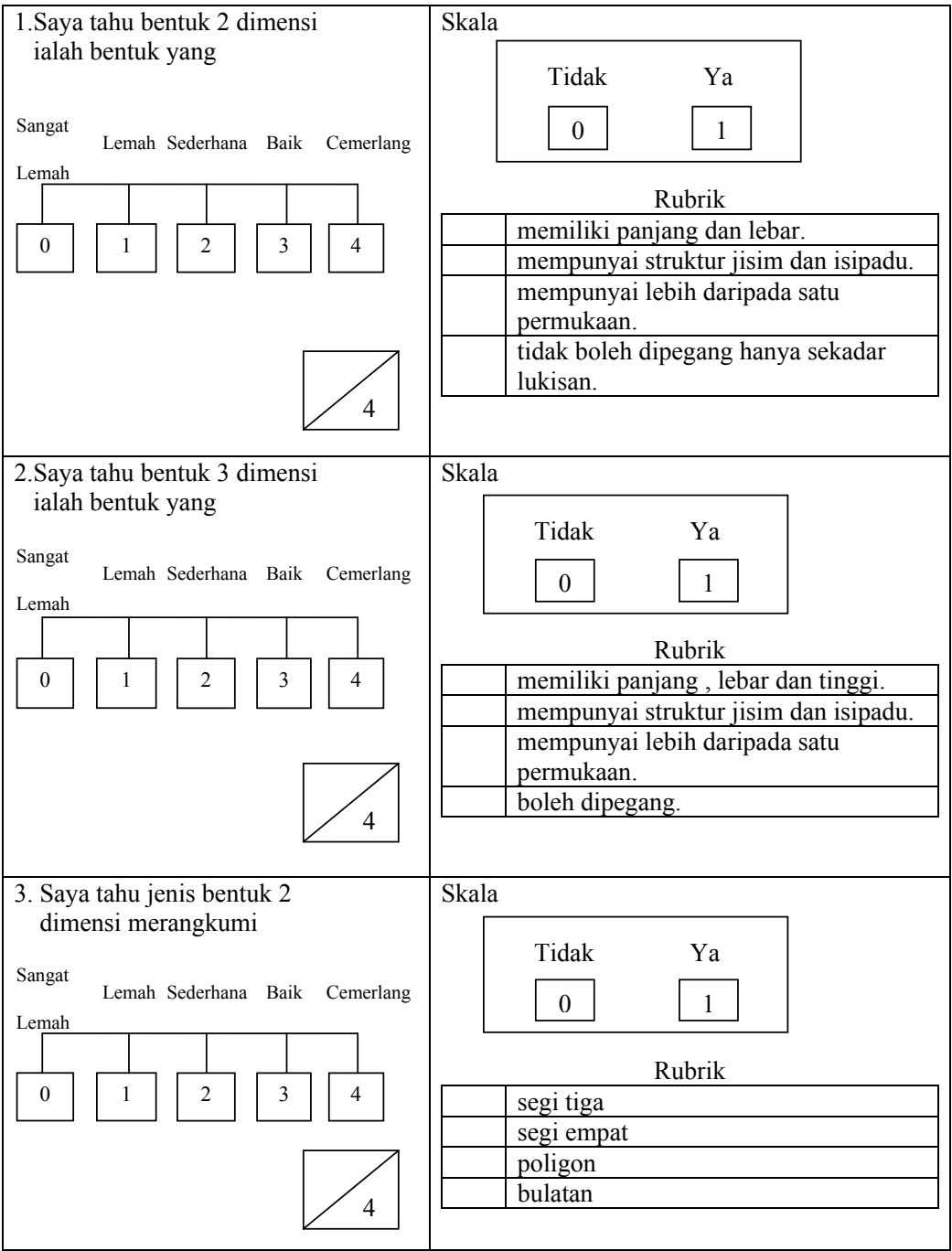




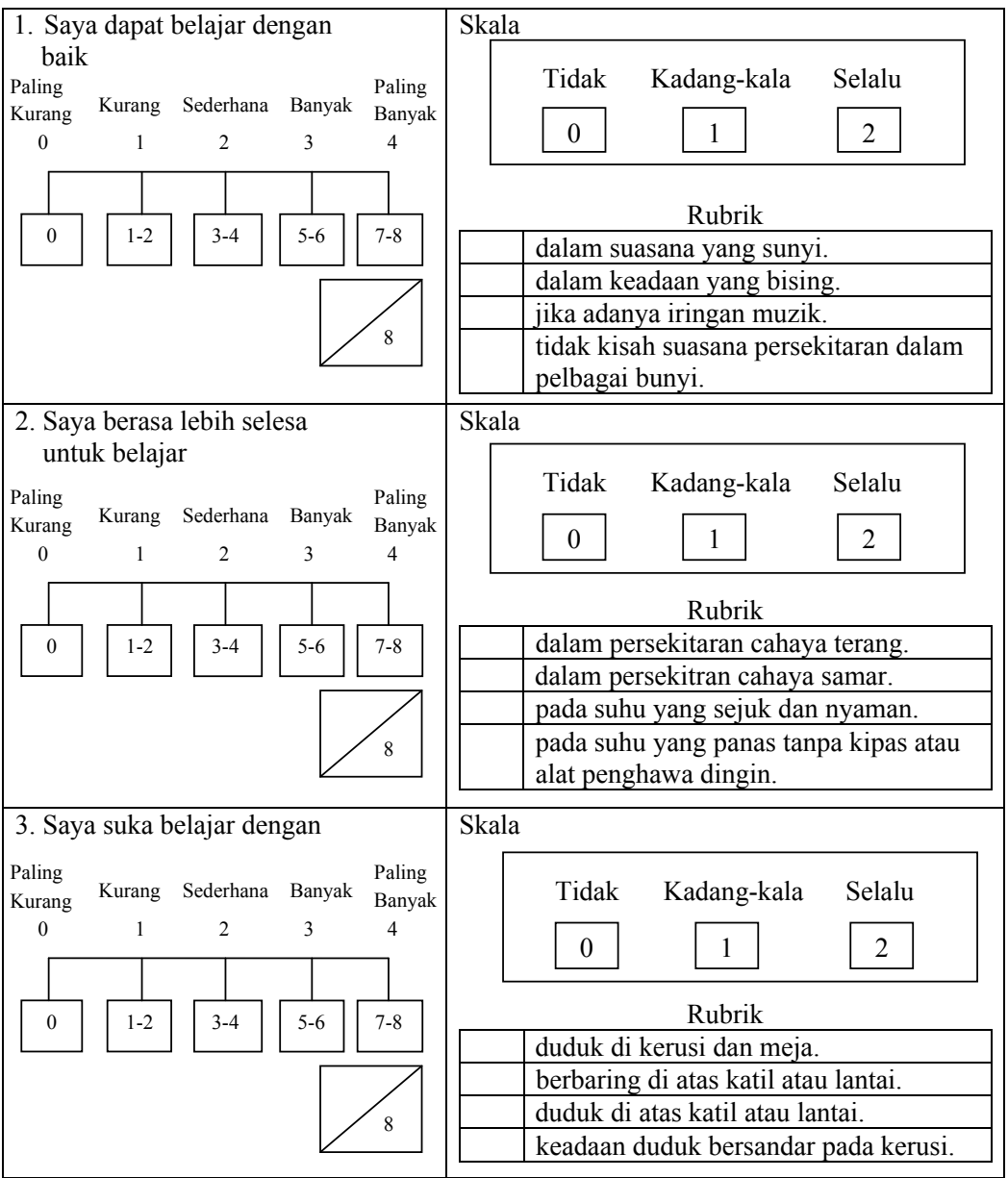

\section{Fasa 3: Kesahan dan Kebolehpercayaan Instrumen Kajian}

\section{Pengesahan Instrumen Kajian}

Semakan pakar adalah perlu untuk memastikan ketepatan konstruk serta kejelasan kandungan (Kline, 2005). Justeru, instrumen penilaian yang dibina telah diberikan kepada pakar yang mempunyai kemahiran dalam bidang yang berkaitan untuk disemak bagi memastikan isi kandungannya bersesuaian dan menepati matlamat kajian.

Pemilihan panel pakar adalah terdiri daripada seorang pensyarah universiti dan empat orang guru matematik sekolah menengah 
yang mempunyai pengalaman mengajar mata pelajaran matematik lebih daripada 10 tahun. Selain itu, pakar juga perlu mempunyai pengetahuan yang luas dalam bidang pendidikan.

Semua panel yang dilantik telah diberi penerangan mengenai latar belakang kajian, definisi konsep kajian, operasi konstruk yang terlibat dan tugas penyemakan item yang dibina. Mereka telah diberikan Borang Semakan Pakar Instrumen Penilaian bagi membuat pembetulan dan memberi komen dan cadangan kepada item pada penilaian mereka yang kurang menepati kehendak konstruk. Berdasarkan borang berkenaan, mereka dikehendaki mengesahkan perkara berikut:

i. Konstruk Penilaian Kendiri Pembelajaran Geometri Tingkatan Satu

ii. Item yang mewakili setiap konstruk Penilaian Kendiri Pembelajaran Geometri Tingkatan Satu

Proses seterusnya ialah keputusan penilaian pakar dikumpulkan dan dianalisis. Kumpulan pakar ini telah membuat semakan, memberi maklum balas serta komen terhadap item-item yang dibina dan secara langsung kesahan muka diperoleh. Mereka juga telah mengembalikan semula Borang Penghakiman Pakar seperti di Jadual 5 setelah selesai menyemak item-item instrumen penilaian.

Penyelidik telah merujuk peratusan persetujuan pakar dalam penerimaan item yang digunapakaikan oleh Mohd Sahandri et al. (2013) dari buku panduan pembinaan instrumen "Anda dan Kepenggunaan". Berdasarkan maklum balas serta komen daripada kumpulan pakar, penempatan item menurut konstruk yang ditentukan dikekalkan jika sekurang-kurangnya $80 \%$ pakar bersetuju bahawa item berkenaan sesuai dengan konstruk yang telah ditetapkan. Item yang mendapat kurang daripada $60 \%$ persetujuan pakar maka item berkenaan disingkirkan. Manakala item yang mencapai persetujuan pakar di antara 60\% - 80\% diubahsuai dan dimurnikan berdasarkan nasihat, cadangan, komen serta perbincangan dengan kumpulan pakar. Jadual 5 menunjukkan komen keseluruhan panel penilai instrumen. 
Jadual 5

Komen Keseluruhan Panel Penilai Instrumen

\begin{tabular}{lccccc}
\hline & \multicolumn{5}{c}{ Pakar } \\
\cline { 2 - 6 } & 1 & 2 & 3 & 4 & 5 \\
\hline Ketepatan penggunaan konstruk & Ya & Ya & Ya & Ya & Ya \\
Format instrumen kajian & Ya & Ya & Ya & Ya & Ya \\
Kejelasan makna setiap item & Ya & Ya & Ya & Baiki & Ya \\
Kesesuaian bahasa yang digunakan & Ya & Baiki & Baiki & Ya & Ya \\
Kesesuaian saiz tulisan & Ya & Ya & Ya & Ya & Ya \\
Kejelasan tentang arahan yang diberikan & Baiki & Ya & Ya & Ya & Ya \\
Penggunaan jarak tulisan & Ya & Ya & Ya & Ya & Ya \\
Petunjuk bagi skala pengukuran & Ya & Ya & Ya & Ya & Ya \\
Kejelasan objektif instrumen & Ya & Ya & Ya & Ya & Ya \\
Ejaan betul & Baiki & Ya & Ya & Baiki & Baiki \\
Ulasan am & Sesuai & Sesuai & Sesuai & Sesuai & Sesuai \\
\hline
\end{tabular}

\section{Kebolehpercayaan Instrumen Kajian}

Kebolehpercayaan merujuk kepada ketekalan atau kestabilan keputusan pentaksiran (Azizi Ahmad, 2010). Ini bermakna seseorang individu itu akan mendapat skor yang sama daripada sesuatu instrumen seandainya kebolehan individu itu adalah tekal atau trait yang hendak diukur itu tidak berubah walaupun diukur berkali-kali dengan instrumen yang sama. Justeru, penyelidik menggunakan kaedah ketekalan dalaman bagi menentukan pekali kebolepercayaan iaitu mencari pekali alfa atau dikenali sebagai Cronbach Alpha bagi setiap konstruk dan keseluruhan instrumen penilaian tersebut melalui program Statistical Package for Social Science (SPSS). Dalam kajian ini, setiap item yang dibina daripada JSI yang berdasarkan kajian literatur adalah tidak wajar untuk melakukan analisis faktor (Mohd Sahandri Gani et al., 2014). Ini adalah kerana Chua (2006) menyatakan bahawa bagi menentukan item individu yang harus dikekalkan atau disingkirkan, data-data kajian rintis boleh dianalisis dengan analisis item (item analysis) menggunakan program pekali kebolehpercayaan Cronbach Alpha.

Untuk memastikan kebolehpercayaan instrumen penilaian kendiri pembelajaran geometri Tingkatan Satu yang diperolehi berada pada tahap memuaskan, penyelidik telah menjalankan kajian rintis dan 
kajian sebenar. Tujuan menjalankan kedua-dua kajian ini adalah untuk melihat kestabilan nilai Cronbach Alpha yang diperoleh. Nilai pekali kebolepercayaan yang diperoleh daripada hasil kajian rintis dan kajian sebenar dianalisis dan dibandingkan dengan Jadual Nilai Kebolehpercayaan (Lim, 2007) bagi mengenal pasti item yang memerlukan penambahbaikan, pengubahsuaian atau disingkirkan dari instrumen kajian yang dibina. Jadual Nilai Kebolehpercayaan boleh dijadikan panduan dalam menaksir kebolehterimaan instrumen kajian dari segi kebolehpercayaan berasaskan nilai pekali kebolehpercayaan (Lim, 2007) seperti di Jadual 6.

Jadual 6

\section{Panduan Tahap Nilai Pekali Kebolehpercayaan}

\begin{tabular}{cc}
\hline Pekali kebolehpercayaan & Tahap kebolehpercayaan \\
\hline 0.90 atau lebih & Amat baik \\
$0.80-0.89$ & Baik \\
$0.60-0.79$ & Sederhana \\
$0.40-0.59$ & Diragui \\
$0.00-0.39$ & Ditolak \\
\hline
\end{tabular}

\section{Persampelan}

Populasi sasaran kajian ini adalah murid Tingkatan Dua sekolah menengah di daerah Kuala Kangsar, Perak. Murid Tingkatan Dua dipilih kerana penilaian ini dilakukan ke atas pembelajaran geometri Tingkatan Satu. Hal ini adalah kerana murid Tingkatan Satu mempelajari tajuk-tajuk geometri pada hujung tahun pengajian mereka.

Bagi kajian ini, penyelidik memilih kaedah persampelan kelompok. Kaedah ini dipilih kerana kajian yang dilakukan ke atas populasi melibatkan kawasan yang luas dan bilangan subjek yang banyak dalam populasi (Lim, 2007). Maka, penyelidik memilih persampelan kelompok berdasarkan sekolah secara rawak di mana yang disampel sebenarnya adalah tempat-tempat yang dinyatakan. Sampel kajian yang dipilih digunakan dalam perlaksanaan kajian rintis dan kajian sebenar. Menurut maklumat yang diperoleh melalui portal Pejabat Pendidikan Daerah Kuala Kangsar, terdapat sebanyak 22 buah 
sekolah menengah di daerah ini. Dalam pemilihan sampel kajian rintis menurut Chua (2006), sampel yang dicadangkan adalah sejumlah 30 hingga 40 responden. Oleh itu, penyelidik memilih 60 orang murid Tingkatan Dua di sebuah sekolah menengah dalam perlaksanaan kajian rintis dengan menggunakan persampelan kelompok dua peringkat.

Manakala, bagi kajian sebenar, jumlah bilangan murid Tingkatan Dua yang diperolehi daripada Pejabat Pendidikan Daerah Kuala Kangsar, Perak adalah sebanyak 2925 orang seperti yang ditunjukkan di Jadual 7. Mengikut Krejcie dan Morgan (1970) dalam Jadual Penentuan Saiz Sampel, bagi populasi seramai 3000 orang, saiz sampel adalah sebanyak 341 orang. Berdasarkan cadangan ini, penyelidik menggunakan persampelan kelompok satu peringkat untuk memilih tiga buah sekolah menengah dalam daerah tersebut sebagai sampel, maka jumlah saiz sampel yang diperoleh adalah seramai 419 orang. Sebelum data dianalisis, penyelidik menggugurkan 19 sampel kerana didapati tidak memberi respon dengan baik dalam instrumen penilaian. Selain itu, responden tidak menjawab instrumen dengan lengkapnya. Oleh itu, sampel akhir untuk kajian sebenar ialah 400 orang.

Jadual 7

Murid Tingkatan Dua Sekolah Menengah di Daerah Kuala Kangsar

\begin{tabular}{llc}
\hline & Sekolah Menengah & Bilangan Murid (orang) \\
\hline 1. & SMKBM & 161 \\
2. & SMKT & 104 \\
3. & SMKTMAA & 146 \\
4. & SMKSB & 199 \\
5. & SMKM & 128 \\
6. & SMKRLKTF & 102 \\
7. & SMKS & 90 \\
8 & SMKRMM & 136 \\
9. & SMKTS & 190 \\
10. & KMKK & 115 \\
11. & SMKME & 120 \\
12. & SMKSC & 316 \\
13. & SMKDHAW & 192 \\
\hline & & (sambungan)
\end{tabular}




\begin{tabular}{llc}
\hline & Sekolah Menengah & Bilangan Murid (orang) \\
\hline 14. & SMKC & 173 \\
15. & SMKRPK & 198 \\
16. & SMKSTA & 113 \\
17. & SMKTP & 170 \\
18. & SMAAD & 54 \\
19. & SMAMAM & 128 \\
20. & SMAMNF & 36 \\
21. & MAL & 54 \\
22. & SMVKK & - \\
\hline & Jumlah & $\mathbf{2 9 2 5}$ \\
\hline
\end{tabular}

\section{Penilaian Kendiri Murid}

Satu lembaran penilaian kendiri telah dihasilkan supaya murid dapat membuat penilaian sendiri setelah sesorang murid tersebut telah menjawab instrumen penilaian. Lembaran ini disediakan juga bagi tujuan pengiraan skor setiap konstruk.

Kaedah penentuan skor bagi kelima-lima konstruk dalam instrumen ini ditentukan dengan mengira min skor bagi item-item di bawah setiap konstruk berkenaan. Hasil data yang diperoleh daripada maklum balas murid dalam instrumen ini dianalisis dengan menggunakan perisian SPSS.

Seseorang penyelidik boleh menggunakan pelbagai teori dan formula sendiri untuk mencipta indeks mereka sendiri berdasarkan keperluan kajian. Dalam kajian ini, penyelidik merujuk kepada penentuan tahap daripada Davies (1971) dan Mohd Sahandri Gani et al. (2013) untuk mengkelaskan tahap-tahap skor min yang diperoleh. Davies (1971) menggunakan skala lima mata dalam menentukan tiga tahap iaitu rendah, sederhana dan tinggi untuk mentafsir skor min. Menurut beliau, nilai skor tertinggi ditolak dengan skor rendah kemudian dibahagikan kepada tahap-tahap yang dikehendaki. Oleh itu, penyelidik telah menetapkan lima tahap tafsiran skor min yang diperoleh dalam kajian ini. Nilai skor min yang diperoleh dibundarkan kepada satu tempat perpuluhan.

Rajah 2 merupakan rumus yang digunakan untuk menentukan tahaptahap tafsiran dalam kajian ini. 
Penentuan skor tahap $=\frac{\text { nilai skor tertinggi dalam skala } 5 \text { mata }- \text { nilai skor terendah dalam } 5 \text { mata }}{\text { Penentuan tahap tafsiran }}$

Rajah 2. Rumus untuk menentukan tahap-tahap tafsiran

Berikut merupakan cara pengiraan untuk menentukan skor tahap.

Penentuan skor tahap

$=\frac{4-0}{5}$

$=\frac{4}{5}$

$=0.8$

Di mana:

$4=$ nilai skor tertinggi dalam skala 5 mata

$0=$ nilai skor terendah dalam skala 5 mata

$5=$ penentu tahap tafsiran

$0.8=$ selang kelas bagi setiap tahap

\section{Penentuan Skor Tahap}

Terdapat dua penggunaan bentuk penentuan skor tahap yang digunapakai oleh penyelidik dalam kajian ini. Bagi bentuk pertama, skor min yang diperoleh menentukan tahap penguasaan murid terhadap pengetahuan sedia ada dan kefahaman dalam geometri. Penentuan tahap-tahap tersebut adalah berdasarkan nilai skor min sebagaimana yang ditunjukkan dalam Jadual 8.

Jadual 8

Penentuan tahap berdasarkan skor min bagi konstruk Pengetahuan Sedia Ada Murid dan Kefahaman Murid dalam Geometri

\begin{tabular}{cc}
\hline Skor min & Tafsiran \\
\hline $0.0-0.8$ & Sangat lemah \\
$0.9-1.6$ & Lemah \\
$1.7-2.4$ & Sederhana \\
$2.5-3.2$ & Baik \\
$3.3-4.0$ & Cemerlang \\
\hline
\end{tabular}

Diadaptasi dari Buku panduan pembinaan instrumen "Anda dan Kepenggunaan”, Mohd Sahandri Gani Hamzah et al. (2013). 
Bagi bentuk kedua, skor min yang diperoleh menentukan pemboleh ubah manakah mempunyai pengaruh yang utama dalam setiap konstruk yang terlibat. Penentuan tahap-tahap tersebut adalah berdasarkan nilai skor min sebagaimana yang ditunjukkan dalam Jadual 9.

Jadual 9

Penentuan tahap berdasarkan skor min bagi konstruk Gaya Pembelajaran Murid, Sikap Pembelajaran Murid dan Pendekatan Pengajaran Guru

\begin{tabular}{cc}
\hline Skor min & Tafsiran \\
\hline $0.0-0.8$ & Paling kurang \\
$0.9-1.6$ & Kurang \\
$1.7-2.4$ & Sederhana \\
$2.5-3.2$ & Banyak \\
$3.3-4.0$ & Paling \\
\hline
\end{tabular}

Diadaptasi dari Buku panduan pembinaan instrumen "Anda dan Kepenggunaan”, Mohd Sahandri Gani et al. (2013).

Dengan bantuan skor tahap yang disediakan, murid mendapat suatu gambaran keseluruhan mengenai pembelajaran geometri mereka dengan lebih jelas dan tepat.

\section{Contoh Penilaian Instrumen Seorang Murid dalam Lembaran Pemarkahan Kendiri}

Untuk membantu pembaca lebih memahami cara penilaian instrumen yang dibina, penyelidik telah menggunakan satu set data contoh instrumen penilaian yang diisi oleh seorang murid bagi tujuan menerangkan penggunaan lembaran pemarkahan kendiri yang dihasilkan. Berikut merupakan satu contoh lembaran pemarkahan kendiri bagi penilaian seorang murid.

\section{Contoh Lembaran Pemarkahan Kendiri} Konstruk A: Pengetahuan Sedia Ada Arahan: 
Sila jumlahkan skor rubrik pada setiap item dalam instrumen penilaian. Kemudian jumlah skor rubrik yang diperoleh bagi setiap item diisi dalam ruangan skor jadual dibawah berpandukan skala 5 mata berikut:

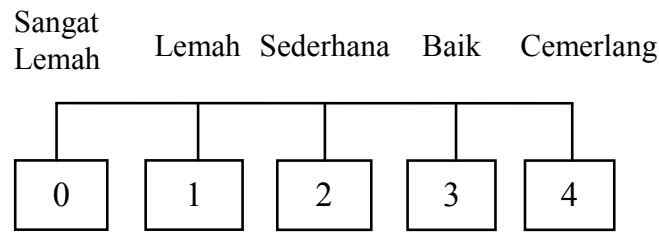

Selepas itu, semua skor dijumlahkan dan dibahagi dengan bilangan item yang ada pada konstruk tersebut. Skor min yang diperoleh menentukan tahap penguasaan berdasarkan tafsiran berikut:

\section{Tahap Penguasaan}

\begin{tabular}{cc}
\hline Skor $\min$ & Tafsiran \\
\hline $0.0-0.8$ & Sangat lemah \\
$0.9-1.6$ & Lemah \\
$1.7-2.4$ & Sederhana \\
$2.5-3.2$ & Baik \\
$3.3-4.0$ & Cemerlang \\
\hline
\end{tabular}

\begin{tabular}{|c|c|c|c|}
\hline Pemboleh ubah & Trait & $\begin{array}{l}\text { No. } \\
\text { Item }\end{array}$ & Skor \\
\hline \multirow{14}{*}{$\begin{array}{l}\text { Pengetahuan seko- } \\
\text { lah rendah }\end{array}$} & \multirow[t]{2}{*}{ Definisi bentuk 2 dimensi dan 3 dimensi } & A1 & 2 \\
\hline & & $\mathrm{A} 2$ & 3 \\
\hline & \multirow[t]{2}{*}{ Jenis bentuk 2 dimensi dan 3 dimensi } & A3 & 3 \\
\hline & & A4 & 3 \\
\hline & \multirow[t]{6}{*}{ Ciri-ciri bentuk 2 dimensi dan 3 dimensi } & A5 & 4 \\
\hline & & A6 & 2 \\
\hline & & A7 & 2 \\
\hline & & $\mathrm{A} 8$ & 2 \\
\hline & & A9 & 4 \\
\hline & & A10 & 4 \\
\hline & \multirow[t]{2}{*}{ Rumus bagi perimeter, luas dan isipadu } & A11 & 4 \\
\hline & & A12 & 3 \\
\hline & Jumlah Skor & & 36 \\
\hline & Skor Min $=\frac{\text { Jumlah Skor }}{12}$ & & $\frac{36}{12}=3.0$ \\
\hline
\end{tabular}

*Catatan: Nilai skor min dibundarkan kepada satu tempat perpuluhan. Tahap Penguasaan: Baik 


\section{Konstruk B: Kefahaman Murid dalam Geometri Tingkatan Satu}

Arahan:

Sila jumlahkan skor rubrik pada setiap item dalam instrumen penilaian. Kemudian jumlah skor rubrik yang diperoleh bagi setiap item diisi dalam ruangan skor jadual dibawah berpandukan skala 5 mata berikut:

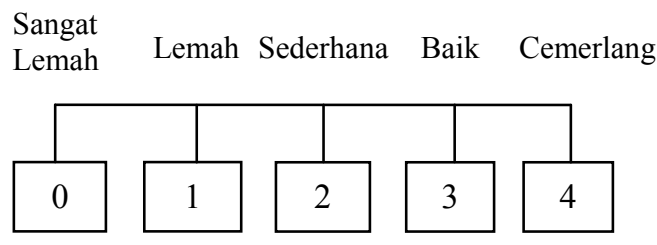

Selepas itu, semua skor dijumlahkan dan dibahagi dengan bilangan item yang ada pada konstruk tersebut. Skor min yang diperoleh menentukan tahap penguasaan berdasarkan tafsiran berikut:

\section{Tahap Penguasaan}

\begin{tabular}{cc}
\hline Skor min & Tafsiran \\
\hline $0.0-0.8$ & Sangat lemah \\
$0.9-1.6$ & Lemah \\
$1.7-2.4$ & Sederhana \\
$2.5-3.2$ & Baik \\
$3.3-4.0$ & Cemerlang \\
\hline
\end{tabular}

\begin{tabular}{lccc}
\hline Pemboleh ubah & \multicolumn{1}{c}{ Trait } & No. Item & Skor \\
\hline Sukatan pelajaran & Sudut dan Garis & B1 & 3 \\
Tingkatan Satu & B2 & 3 \\
& B3 & 3 \\
& B4 & 4 \\
& B5 & 4 \\
& B6 & 2 \\
& B7 & 4 \\
& B8 & 3 \\
& B9 & 2 \\
\hline
\end{tabular}




\begin{tabular}{|c|c|c|c|}
\hline Pemboleh ubah & Trait & No. Item & Skor \\
\hline \multirow{14}{*}{\multicolumn{2}{|c|}{ Poligon }} & B10 & 3 \\
\hline & & B11 & 4 \\
\hline & & B12 & 3 \\
\hline & & $\mathrm{B} 13$ & 3 \\
\hline & & B14 & 4 \\
\hline & & B15 & 4 \\
\hline & & B16 & 2 \\
\hline & & B17 & 3 \\
\hline & & B18 & 3 \\
\hline & & B19 & 3 \\
\hline & & B20 & 3 \\
\hline & & B21 & 3 \\
\hline & & B22 & 4 \\
\hline & & B23 & 4 \\
\hline \multirow{2}{*}{\multicolumn{2}{|c|}{ Perimeter dan Luas }} & B24 & 4 \\
\hline & & $\mathrm{B} 25$ & 4 \\
\hline \multirow{5}{*}{\multicolumn{2}{|c|}{ Pepejal Geometri }} & B26 & 4 \\
\hline & & B27 & 3 \\
\hline & & B28 & 4 \\
\hline & & B29 & 4 \\
\hline & & $\mathrm{B} 30$ & 2 \\
\hline \multicolumn{3}{|c|}{ Jumlah Skor } & 99 \\
\hline \multicolumn{2}{|r|}{ Skor Min $=\frac{\text { Jumlah Skor }}{30}$} & \multicolumn{2}{|c|}{$\frac{99}{30}=3.3$} \\
\hline
\end{tabular}

*Catatan: Nilai skor min dibundarkan kepada satu tempat perpuluhan.

Tahap Penguasaan: Cemerlang

\section{Konstruk C: Gaya Pembelajaran Murid}

Arahan:

Sila jumlahkan skor rubrik pada setiap item dalam instrumen penilaian. Kemudian jumlah skor rubrik yang diperoleh bagi setiap item diisi dalam ruangan skor jadual dibawah berpandukan skala 5 mata berikut:

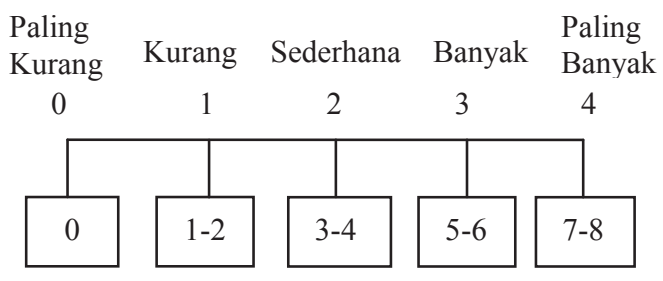


Contoh pengisian skor bagi setiap item:

Jika jumlah skor yang diperoleh ialah 6 bagi suatu item, maka skor item itu ialah 3.

Selepas semua skor item diisikan bagi setiap pemboleh ubah, skor item-item tersebut dijumlahkan dan dibahagi dengan bilangan item yang ada pada pemboleh ubah tersebut. Skor min yang diperoleh menentukan pemboleh ubah manakah mempunyai pengaruh yang utama berdasarkan tahap pengaruh yang telah ditetapkan seperti berikut:

\section{Tahap Pengaruh}

\begin{tabular}{cc}
\hline Skor min & Tafsiran \\
\hline $0.0-0.8$ & Paling kurang \\
$0.9-1.6$ & Kurang \\
$1.7-2.4$ & Sederhana \\
$2.5-3.2$ & Banyak \\
$3.3-4.0$ & Paling banyak \\
\hline
\end{tabular}

\begin{tabular}{|c|c|c|c|}
\hline $\begin{array}{l}\text { Pemboleh } \\
\text { ubah }\end{array}$ & Trait & $\begin{array}{l}\text { No. } \\
\text { Item }\end{array}$ & Skor \\
\hline \multirow[t]{5}{*}{ Persekitaran } & Suasana pembelajaran & $\mathrm{C} 1$ & 2 \\
\hline & & $\mathrm{C} 2$ & 2 \\
\hline & & $\mathrm{C} 3$ & 2 \\
\hline & Jumlah Skor & & 6 \\
\hline & Skor Min $=\frac{\text { Jumlah Skor }}{3}$ & & $\frac{6}{3}=2.0$ \\
\hline \multirow[t]{6}{*}{ Emosional } & Perasaan dan tindakan murid & $\mathrm{C} 4$ & 3 \\
\hline & & $\mathrm{C} 5$ & 3 \\
\hline & & C6 & 3 \\
\hline & & $\mathrm{C} 7$ & 3 \\
\hline & Jumlah Skor & & 12 \\
\hline & Skor Min $=\frac{\text { Jumlah Skor }}{4}$ & & $\frac{12}{4}=3.0$ \\
\hline \multirow[t]{5}{*}{ Sosiologi } & Cara pergaulan & $\mathrm{C} 8$ & 3 \\
\hline & & $\mathrm{C} 9$ & 4 \\
\hline & & $\mathrm{C} 10$ & 3 \\
\hline & Jumlah Skor & & 10 \\
\hline & Skor Min $=\frac{\text { Jumlah Skor }}{3}$ & & $\frac{10}{3}=3.3$ \\
\hline
\end{tabular}




\begin{tabular}{|c|c|c|c|}
\hline $\begin{array}{l}\text { Pemboleh } \\
\text { ubah }\end{array}$ & Trait & $\begin{array}{l}\text { No. } \\
\text { Item }\end{array}$ & Skor \\
\hline \multirow[t]{7}{*}{ Fizikal } & Pengamatan & $\mathrm{C} 11$ & 3 \\
\hline & & $\mathrm{C} 12$ & 3 \\
\hline & Masa/ pergerakan & $\mathrm{C} 13$ & 2 \\
\hline & & $\mathrm{C} 14$ & 2 \\
\hline & & $\mathrm{C} 15$ & 3 \\
\hline & Jumlah Skor & & 13 \\
\hline & Skor Min $=\frac{\text { Jumlah Skor }}{5}$ & & $\frac{13}{5}=2.6$ \\
\hline \multirow[t]{3}{*}{ Psikologi } & $\begin{array}{l}\text { Global atau analitik, Otak kiri atau otak kanan, } \\
\text { impulsif atau reflektif }\end{array}$ & $\mathrm{C} 16$ & 3 \\
\hline & Jumlah Skor & & 3 \\
\hline & Skor Min $=\frac{\text { Jumlah Skor }}{1}$ & & $\frac{3}{1}=3.0$ \\
\hline
\end{tabular}

*Catatan: Nilai skor min dibundarkan kepada satu tempat perpuluhan.

Pengaruh Utama : $\underline{\text { Sosiologi }}$

\section{Konstruk D: Sikap Pembelajaran Murid}

Arahan:

Sila jumlahkan skor rubrik pada setiap item dalam instrumen penilaian. Kemudian jumlah skor rubrik yang diperoleh bagi setiap item diisi dalam ruangan skor jadual dibawah berpandukan skala 5 mata berikut:

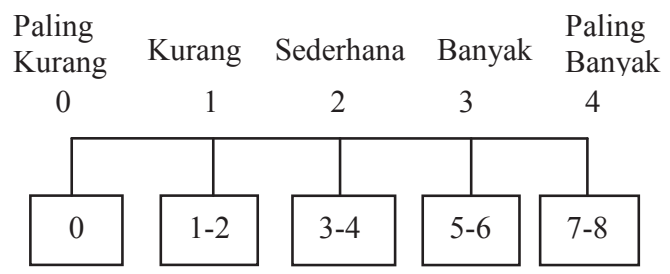

Contoh pengisian skor bagi setiap item:

Jika jumlah skor yang diperoleh ialah 6 bagi suatu item, maka skor item itu ialah 3.

Selepas semua skor item diisikan bagi setiap pemboleh ubah, skor item-item tersebut dijumlahkan dan dibahagi dengan bilangan item yang ada pada pemboleh ubah tersebut. Skor min yang diperoleh 
menentukan pemboleh ubah manakah mempunyai pengaruh yang utama berdasarkan tahap pengaruh yang telah ditetapkan seperti berikut:

\section{Tahap Pengaruh}

\begin{tabular}{cc}
\hline Skor $\min$ & Tafsiran \\
\hline $0.0-0.8$ & Paling kurang \\
$0.9-1.6$ & Kurang \\
$1.7-2.4$ & Sederhana \\
$2.5-3.2$ & Banyak \\
$3.3-4.0$ & Paling banyak \\
\hline
\end{tabular}

\begin{tabular}{|c|c|c|c|}
\hline $\begin{array}{l}\text { Pemboleh } \\
\text { ubah }\end{array}$ & Trait & $\begin{array}{l}\text { No. } \\
\text { Item }\end{array}$ & Skor \\
\hline \multirow[t]{6}{*}{ Motivasi } & Pemikiran positif & D1 & 4 \\
\hline & & D2 & 2 \\
\hline & & D3 & 3 \\
\hline & & D4 & 3 \\
\hline & Jumlah Skor & & 12 \\
\hline & Skor Min $=\frac{\text { Jumlah Skor }}{4}$ & & $\frac{12}{4}=3.0$ \\
\hline \multirow[t]{5}{*}{ Minat } & Kesediaan belajar & D5 & 3 \\
\hline & & D6 & 3 \\
\hline & Keutamaan kefahaman murid & D7 & 3 \\
\hline & Jumlah Skor & & 9 \\
\hline & Skor Min $=\frac{\text { Jumlah Skor }}{3}$ & & $\frac{9}{3}=3.0$ \\
\hline \multirow[t]{4}{*}{ Keyakinan } & Yakin diri & D8 & 3 \\
\hline & Kecekapan & D9 & 3 \\
\hline & Jumlah Skor & & 6 \\
\hline & Skor Min $=\frac{\text { Jumlah Skor }}{2}$ & & $\frac{6}{2}=3.0$ \\
\hline
\end{tabular}

*Catatan: Nilai skor min dibundarkan kepada satu tempat perpuluhan.

Pengaruh Utama : Motivasi, minat dan keyakinan 


\section{Konstruk E: Pendekatan Pengajaran Guru}

Arahan:

Sila jumlahkan skor rubrik pada setiap item dalam instrumen penilaian. Kemudian jumlah skor rubrik yang diperoleh bagi setiap item diisi dalam ruangan skor jadual dibawah berpandukan skala 5 mata berikut:

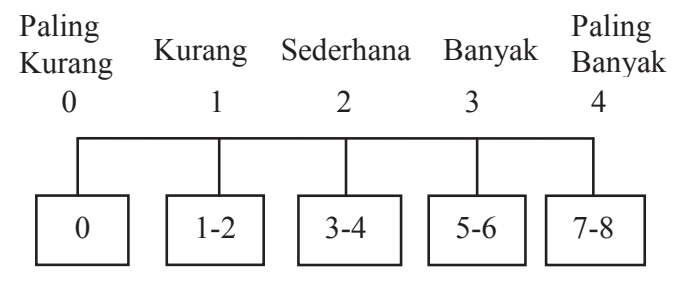

Contoh pengisian skor bagi setiap item:

Jika jumlah skor yang diperoleh ialah 6 bagi suatu item, maka skor item itu ialah 3.

Selepas semua skor item diisikan bagi setiap pemboleh ubah, skor item-item tersebut dijumlahkan dan dibahagi dengan bilangan item yang ada pada pemboleh ubah tersebut. Skor min yang diperoleh menentukan pemboleh ubah manakah mempunyai pengaruh yang utama berdasarkan tahap pengaruh yang telah ditetapkan seperti berikut:

$\underline{\text { Tahap Pengaruh }}$

\begin{tabular}{cc}
\hline Skor min & Tafsiran \\
\hline $0.0-0.8$ & Paling kurang \\
$0.9-1.6$ & Kurang \\
$1.7-2.4$ & Sederhana \\
$2.5-3.2$ & Banyak \\
$3.3-4.0$ & Paling banyak \\
\hline
\end{tabular}




\begin{tabular}{|c|c|c|c|}
\hline Pemboleh ubah & Trait & $\begin{array}{l}\text { No. } \\
\text { Item }\end{array}$ & Skor \\
\hline \multirow{7}{*}{$\begin{array}{l}\text { Strategi pembelajaran } \\
\text { dan pengajaran }\end{array}$} & \multirow{5}{*}{$\begin{array}{l}\text { Proses pembelajaran dan pengajaran } \\
\text { guru dalam kelas }\end{array}$} & E1 & 3 \\
\hline & & E2 & 3 \\
\hline & & E3 & 3 \\
\hline & & E4 & 4 \\
\hline & & E5 & 4 \\
\hline & Jumlah Skor & & 17 \\
\hline & Skor Min $=\frac{\text { Jumlah Skor }}{5}$ & & $\frac{17}{5}=3.4$ \\
\hline \multirow{7}{*}{$\begin{array}{l}\text { Bahan bantu menga- } \\
\text { jar (BBM) }\end{array}$} & Penggunaan BBM & E6 & 3 \\
\hline & & E7 & 3 \\
\hline & Bahan bercetak & E8 & 4 \\
\hline & Bahan bukan bercetak & E9 & 3 \\
\hline & Perkakasan & E10 & 3 \\
\hline & Jumlah Skor & & 16 \\
\hline & Skor Min $=\frac{\text { Jumlah Skor }}{5}$ & & $\frac{16}{5}=3.2$ \\
\hline \multirow[t]{4}{*}{ Komunikasi } & Lisan & E11 & 3 \\
\hline & & E12 & 3 \\
\hline & Jumlah Skor & & 6 \\
\hline & Skor Min $=\frac{\text { Jumlah Skor }}{2}$ & & $\frac{6}{2}=3.0$ \\
\hline
\end{tabular}

*Catatan: Nilai skor min dibundarkan kepada satu tempat perpuluhan.

Pengaruh Utama : Strategi pembelajaran dan pengajaran

\section{DAPATAN KAJIAN}

\section{Dapatan Kajian Rintis}

Kajian rintis ini melibatkan seramai 60 orang murid Tingkatan Dua. Tujuan kajian rintis adalah untuk memperoleh tahap kebolepercayaan instrumen penilaian dengan menentukan nilai pekali Cronbach Alpha. Selain itu, melalui pelaksanaan kajian rintis ini, penyelidik dapat mengenal pasti tempoh masa yang diambil oleh responden kajian untuk menjawab instrumen penilaian dan memastikan sama ada isi kandungan instrumen ini dapat difahami. Masa yang diambil oleh responden kajian adalah dalam lingkungan 55-60 minit. 
Bagi menentukan sama ada item yang dibina diterima atau disingkirkan, penyelidik membuat perbandingan nilai Cronbach Alpha jika item disingkirkan (Alpha If Item Deleted) bagi setiap item dengan nilai Cronbach Alpha bagi konstruk yang terlibat dalam instrumen tersebut. Menurut Chua (2006), jika sesuatu item dalam konstruk itu mempunyai nilai Cronbach Alpha jika item disingkirkan lebih tinggi daripada nilai Cronbach Alpha bagi konstruk tersebut, maka item itu perlu disingkirkan. Ini bererti pekali alpha tidak akan meningkat lagi dengan menyingkirkan mana-mana item dalam konstruk tersebut. Tiada item lain dalam instrumen kajian ini akan disingkirkan.

Penyelidik memaparkan dapatan kajian rintis mengenai instrumen penilaian bagi responden Tingkatan Dua pada Jadual 9. Jadual 9 menunjukkan pekali kebolehpercayaan yang telah diperoleh bagi kesemua lima konstruk dalam instrumen penilaian bagi murid Tingkatan Dua. Berdasarkan Jadual 9, didapati bahawa nilai Cronbach Alpha adalah di antara julat 0.722 hingga 0.945 . Nilai Cronbach Alpha yang tertinggi ialah 0.945 bagi konstruk kefahaman murid dalam Geometri. Manakala nilai Cronbach Alpha yang paling rendah ialah 0.722 bagi konstruk gaya pembelajaran murid. Sementara itu, keputusan analisis menunjukkan bahawa nilai Cronbach Alpha keseluruhan bagi instrumen penilaian ini ialah 0.955. Ini menunjukkan bahawa instrumen penilaian ini mempunyai nilai kebolehpercayaan yang amat tinggi.

Jadual 9

Ringkasan Analisis Kebolehpercayaan Instrumen Penilaian bagi Kajian Rintis

\begin{tabular}{lccc}
\hline \multicolumn{1}{c}{ Konstruk } & $\begin{array}{c}\text { Bilangan } \\
\text { Item }\end{array}$ & $\begin{array}{c}\text { Nilai } \\
\text { Alpha }\end{array}$ & Interpretasi \\
\hline Pengetahuan Sedia Ada & 12 & 0.908 & Amat baik \\
Kefahaman Murid dalam Geometri & 30 & 0.945 & Amat baik \\
Gaya Pembelajaran Murid & 16 & 0.722 & Sederhana \\
Sikap Pembelajaran Murid & 9 & 0.754 & Sederhana \\
Pendekatan Pengajaran Guru & 12 & 0.867 & Baik \\
\hline Nilai keseluruhan Cronbach Alpha & & $\mathbf{0 . 9 5 5}$ & Amat baik \\
instrument penilaian & & & \\
\hline
\end{tabular}




\section{Dapatan Kajian Sebenar}

Kajian ini dilakukan untuk melihat sama ada nilai pekali kebolehpercayaan yang didapati adalah stabil bagi setiap konstruk yang telah ditetapkan jika dibandingkan dengan kajian rintis sebelum ini. Seramai 400 orang murid Tingkatan Dua terlibat dalam kajian sebenar ini. Semua nilai kebolehpercayaan diinterpretasi berdasarkan Jadual Nilai Kebolehpercayaan (Lim, 2007). Menurut Borg et al. (1993) dan Mohd Majid (1990) menyatakan bahawa nilai alpha berangka 0.60 atau lebih adalah baik dan boleh diterima. Manakala Pallant (2010) pula menerima nilai sekecil 0.60 bagi instrumen yang dibina.

Jadual 10 menunjukkan dapatan kajian sebenar mengenai instrumen penilaian bagi responden Tingkatan Dua. Berdasarkan Jadual 10, didapati bahawa nilai Cronbach Alpha bagi setiap konstruk adalah dalam julat 0.813 hingga 0.940 . Konstruk sikap pembelajaran murid mencatatkan nilai kebolehpercayaan yang paling rendah iaitu 0.813. Manakala, konstruk kefahaman murid dalam Geometri pula mencatatkan nilai kebolehpercayaan yang paling tinggi iaitu 0.940 . Sementara itu, nilai Cronbach Alpha keseluruhan bagi instrumen penilaian ini ialah 0.946 .

Jadual 10

Ringkasan Analisis Kebolehpercayaan Instrumen Penilaian bagi Kajian Sebenar

\begin{tabular}{lccc}
\hline \multicolumn{1}{c}{ Konstruk } & $\begin{array}{c}\text { Bilangan } \\
\text { Item }\end{array}$ & $\begin{array}{c}\text { Nilai } \\
\text { Alpha }\end{array}$ & Interpretasi \\
\hline Pengetahuan Sedia Ada & 12 & 0.865 & Baik \\
Kefahaman Murid dalam Geometri & 30 & 0.940 & Amat baik \\
Gaya Pembelajaran Murid & 16 & 0.835 & Baik \\
Sikap Pembelajaran Murid & 9 & 0.813 & Baik \\
Pendekatan Pengajaran Guru & 12 & 0.846 & Baik \\
\hline Nilai keseluruhan Cronbach Alpha & & $\mathbf{0 . 9 4 6}$ & Amat baik \\
instrument penilaian & & & \\
\hline
\end{tabular}

Kesimpulannya, berdasarkan hasil dapatan kajian sebenar, instrumen penilaian kendiri pembelajaran geometri Tingkatan Satu boleh dikatakan mempunyai nilai kebolehpercayaan yang memuaskan, diterima dan sesuai digunakan dalam kajian ini. 


\section{RUMUSAN}

Pembinaan instrumen penilaian kendiri pembelajaran geometri Tingkatan Satu adalah bertujuan untuk mengenal pasti tahap penguasaan pembelajaran geometri murid di Malaysia. Kajian ini dijalankan berpandukan model penilaian KIPP (konteks-inputproses-produk) yang dikemukakan oleh Stufflebeam (1971). Dengan model ini, penyelidik telah menghasilkan kerangka konseptual yang menggambarkan hubungan antara konteks, input, proses dan produk.

Kajian ini dilaksanakan mengikut tiga fasa. Kajian ini dimulakan dengan pernyataan masalah, kemudian diikuti oleh objektif dan persoalan kajian. Fasa seterusnya ialah analisis kajian-kajian literatur yang membentangkan kajian-kajian yang berkaitan dengan langkah pembinaan instrumen penilaian, model penilaian yang digunakan, prosedur penentuan kesahan dan kebolehpercayaan instrumen serta mengenal pasti instrumen yang berkaitan dengan instrumen yang dibina.

Tahap ketiga pula melibatkan kesahan dan kebolehpercayaan instrumen penilaian yang dibina. Tahap ini menghuraikan prosedur yang diguna pakai oleh penyelidik dalam proses pembinaan instrumen iaitu meliputi pengenalpastian konstruk dan pemboleh ubah yang berkaitan, pengenalpastian trait atau ciri-ciri bagi pemboleh ubah-pemboleh ubah setiap konstruk, pembinaan item, penentuan kesahan, penentuan skor data setiap konstruk, penentuan kebolehpercayaan dan penghasilan instrumen penilaian versi terkini setelah diperbaiki. Jadual Spesifikasi Instrumen digunakan dalam proses pembinaan item-item penilaian. Kemudian kesahan item disemak oleh panel pakar yang berkenaan. Data kuantitatif yang dikumpul dari kajian rintis dan kajian sebenar dianalisis dengan menentukan nilai pekali Cronbach Alpha.

Kajian mengenai pembinaan instrumen penilaian murid terhadap pembelajaran geometri Tingkatan Satu belum pernah dijalankan oleh penyelidik di Malaysia. Justeru, terdapat beberapa cadangan yang boleh diketengahkan dalam kajian bagi tujuan penambahbaikan penghasilan instrumen yang dibina. Ia boleh dijadikan sebagai panduan untuk kegunaan di masa akan datang. 
Sampel bagi kajian ini adalah terdiri daripada kalangan murid Tingkatan Dua sahaja. Justeru, dicadangkan sampel kajian boleh diperluaskan dengan melibatkan murid dari tingkatan yang lain supaya mencakupi pembelajaran geometri yang lebih menyeluruh di sekolah menengah di Malaysia. Instrumen penilaian yang dibina ini adalah merupakan bentuk yang fleksibel di mana instrumen penilaian ini boleh dilaksanakan secara berasingan mengikut konstruk-konstruk yang telah ditetapkan iaitu pengetahuan sedia ada, kefahaman murid dalam Geometri Tingkatan Satu, gaya pembelajaran murid, sikap pembelajaran dan pendekatan pengajaran guru . Ini adalah kerana pemberian skor dan rubrik adalah dinyatakan secara berasingan mengikut konstruk-konstruk.

Sehubungan itu, instrumen penilaian kendiri pembelajaran geometri Tingkatan Satu wajar dibangunkan kerana murid dapat menilai pembelajaran geometri Tingkatan Satu secara kendiri. Di samping itu, bagi pendidik matematik pula, mereka dapat mengetahui tahap pemahaman murid dalam tajuk Geometri dan keperluan pembelajaran murid. Faktor ini merupakan salah satu satu usaha ke arah 'effective pedagogy in mathematics classroom'.

\section{RUJUKAN}

Abdul Halim, Lilia Halim, T. Subahan, Mohd Meerah \& Kamisah Osman. (2010). Pembangunan instrumen penyelesaian masalah sains. Jurnal Pendidikan Malaysia, 35(1), 35 - 39.

Abdul Razak Idris \& Nor Asmah Salleh. (2011). Pendekatan pengajaran yang digunakan oleh guru sekolah menengah di daerah Johor Bahru dalam pengajaran dan pembelajaran matematik. Journal of Science and Mathematics Educational, 3, 134-149.

Aiso Heinze \& Carl von Ossietzy. (2002). “...Because a square is not a rectangle..." Students' knowledge of simple geometrical concepts when starting to learn proof. Diperoleh daripada http://www.lettredelapreuve.org/OldPreuve/PME/ PME26/RRHeinze.pdf

Aysen Ozerem. (2012). Misconceptions in geometry and suggested solutions for seventh grade students. International Journal of New Trends in Arts, Sports \& Science Education, 1(4), 23 - 35. 
Azlina Mohd Kosnin \& Lok Yian Lin (2010). Keberkesanan perisian geometer's sketchpad untuk tajuk Pembinaan Geometri dalam pengajarandan pembelajaran matematik. Diperoleh daripada http://eprints.utm.my/10239/2/Lok_Yian_Lin.pdf

Azizi Ahmad. (2010). Pentaksiran pembelajaran. Kuala Lumpur: Dewan Bahasa dan Pustaka.

Azizi Yahaya, Jamaluddin Ramli \& Yusof Boon. (2010). Sumbangan sikap terhadap pencapaian pelajar dalam mata pelajaran matematik: sejauhmanakah hubungan ini relevan?. Diperoleh Mac 30, 2013 daripada http://eprints.utm.my/2355/1/ Aziziyahaya_Sumbang_Sikap_terhadap_matema tik.pdf

Azlina Mohd Kosnin \& Suhaila Abdullah. (2008). Kesan kaedah pengajaran berbantukan geometer's sketchpad terhadap pencapaian pelajaran dalam topik transformasi. Dalam Seminar Kebangsaan Pendidikan Sains dan Matematik (hal. 1-6). Johor : Universiti Teknologi Malaysia.

Baharuddin Aris, Rio Sumarni Shariffudin \& Manimegalai Subramaniam. (2002). Reka bentuk perisian multimedia (1st ed.). Johor: Penerbit Universiti Teknologi Malaysia.

Black, P. \& Wiliam, D. (1998). Inside the black box: Raising standards through classroom assessment. Phi Delta Kappan, 80 (2), 139-148.

Borg, W. R., Gall, M. D., \& Gall, J. P. (1993). Educational research. New Jersey: Prentice Hall.

Cagri Biber, Abdulkadir Tuna., \& Samet Korkmaz. (2013). The mistakes and the misconceptions of the eighth grade students on the subject and angles. European Journal of Science and Mathematics Education, 1(2), 50 - 59.

Chien, M., Lee, C., \& Cheng, Y. (2007). The construction of Taiwan's educational indicator systems: Experiences and implications. Educational Research for Policy \& Practice, 6(3), 249-259.

Chua Mei Kang, Teh Eng Kiat, Ooi Soo Huat \&., Obaidillah Abdullah. (2011). Matematik Tingkatan 1. Johor Bharu: Penerbitan Pelangi Sdn.Bhd.

Chua Yan Piaw. (2006). Kaedah dan statistik penyelidikan: Kaedah penyelidikan buku 1. Selangor: McGraw- Hill (Malaysia).

Crowley, M. L.(1987). The Van Hiele model of the development of geometric thought. Dalam Learning and Teaching Geometry (pp. 1-16). Reston, VA: National Council of Teachers of Mathematics. 
Gunawardena Egodawatte. (2010). A rubric to self-assess and peer-assess mathematical problem solving tasks of college students. Acta Didactica Napocensia, 3(1), 75-88.

Daniel J. H. (2007). The effects of self-assessment on student learning of mathematics. Diperoleh daripada http://etd. lsu.edu/docs/available/etd-07052010-214944/unrestricted/ Hotard_thesis.pdf

Kakoma Luneta. (2014). Foundation phase teachers' (limited) knowledge of geometry. South African Journal Childhood Education, 4(3), 71-86.

Kartono (2010). Hands on activity pada pembelajaran geometri sekolah sebagai asesmen kinerja siswa. Diperoleh Mei 15, 2013 daripada http://journal.unnes.ac.id/nju/index.php/ kreano/article/view/219/228

Khalid Johari. (2003). Penyelidikan dalam pendidikan: Konsep dan prosedur. Petaling Jaya: Prentice Hall.

Kementerian Pendidikan Malaysia. (1998). Sukatan Pelajaran Sekolah Menengah Matematik. Kuala Lumpur: Dewan Bahasa dan Pustaka.

Kementerian Pendidikan Malaysia. (2010). Sukatan Pelajaran Kurikulum Standard Sekolah Rendah Matematik. Kuala Lumpur: Dewan Bahasa dan Pustaka.

Kementerian Pendidikan Malaysia. (2013). Pelan Pembangunan Pendidikan Malaysia 2013-2025. Putrajaya: Kementerian Pendidikan Malaysia.

Kline, T. (2005). Psychological Testing: A practical approach to design \& evaluation. California: Sage Publication.

Leonard, M. K., Tipps, S., \& Johnson, A. (2004). Guiding children's learning of mathematics (10th ed). United States of America: Thompson Learning, Inc.

Lim Chong Hin. (2007). Penyelidikan pendidikan: Pendekatan kuantiatif dan kualitatif. Selangor: McGraw- Hill (Malaysia).

Matthews, J. M. \& Hudson, A. M. (2001). Guidelines for evaluating parent training projects. Family Relation, 50 (1), 77-86.

Mayberry, J.W. (1983). The van Hiele levels of geometric thought in undergraduate preservice teachers. Journal for Research in Mathematics Education, 14, 58-69.

Mohamad Najib Abdul Ghafar. (2011). Pembinaan dan analisi ujian bilik darjah. Johor Bahru: Penerbit Universiti Teknologi Malaysia Press. 
Mohd Faizal Nizam Lee Abdullah, Sazelli Ab Ghani, Che Nidzam Che Ahmad \& Asmayati Yahaya. (2015). Students'discourse in learning mathematics with self regulating strategies. Procedia Social and Behavioral Science, 191(2015), 2188 - 2194.

Mohd Faizal Nizam Lee Abdullah, Mohd Sahandri Gani Hamzah, Che Nidzam Che Ahmad, Mazlini Adnan, Noraini Mohamed Noh, Shafini Suhaimi \& Lajiman Janoory. (2014a). An instrument to assess secondary school mathematics teachers' assessment practices in Malaysia. Journal of Teaching and Education, 03(03), 483 - 492.

Mohd Faizal Nizam Lee Abdullah, Mohd Sahandri Gani Hamzah, Che Nidzam Che Ahmad, Mazlini Adnan, Noraini Mohamed Noh., \& Shafini Suhaimi. (2014b). Pembinaan instrumen amalan pentaksiran guru matematik sekolah menengah. Jurnal Pendidikan Sains \& Matematik Malaysia, 4(1), 1- 14.

Mohd. Majid Konting. (1990). Kaedah penyelidikan pendidikan. Kuala Lumpur: Dewan Bahasa dan Pustaka.

Mohd Najib. (1997). Pembinaan dan analisis ujian bilik darjah. Johor: UTM.

Mohd Sahandri Gani Hamzah, Laily Paim, Sharifah Azizah Haron., \& Mohd Faizal Nizam Lee Abdullah. (2013). Buku panduan pembinaan instrumen “ Anda dan Kepenggunaan”. Tanjung Malim, Perak: Emeritus Publications.

Mohd Sahandri Gani Hamzah, Noor Shah Saad, Saifuddin Kumar Abdullah, Mazura Mastura Muhammad., \& Husni Zaim Khairun Nasri. (2014). Transformation of research instrument development in education. US-China Education Review A, 4(10), 679-687.

Mokhtar Ismail. (2009). Pentaksiran pendidikan. Kuala Lumpur : Dewan Bahasa dan Pustaka.

Moskal, B.M. (2000). Scoring rubric: What, when and how? Pratical assessment, research \& evaluation, 7(3). Diperolehi daripada http://PAREonline.net/getvn.asp?v=7\&n=3

Noor Azreen Abd Aziz \& Sulaiman Yamin. (2012). Sistem pentaksiran antarabangsa: Satu cadangan di Malaysia. Dalam Prosiding Seminar Pasca Ijazah dalam PTV kali ke-2 (hal. 88-99). Universiti Tun Hussein Onn Malaysia.

Noraini Idris. (2001). Pedagogi dalam pendidikan matematik. Kuala Lumpur: Utusan Publications \& Distributors Sdn. Bhd. 